\title{
Evaporation and abstraction determined from stable isotopes during normal flow on the Gariep River, South Africa
}

\section{Roger E Diamond ${ }^{1}$ and Sam Jack ${ }^{2}$}

${ }^{1}$ Department of Geology, University of Pretoria, South Africa; roger.diamond@up.ac.za

${ }^{2}$ Institute for Plant Conservation, Biology Department, University of Cape Town, South Africa

\section{Keypoints}

- The first full length stable isotope survey of the Gariep River is presented.

- Evaporation on the Gariep River was calculated at about $20 \%$ of flow, or $40 \mathrm{~m}^{3} / \mathrm{s}$.

- Abstraction on the middle reaches of the Gariep River was calculated at $175 \mathrm{~L} / \mathrm{s} / \mathrm{km}$.

- The application of stable isotopes to the hydrology of major water resources is demonstrated.

Keywords: hydrology; stable istopes; evaporation.

\begin{abstract}
Changes in the stable isotope composition of water can, with the aid of climatic parameters, be used to calculate the quantity of evaporation from a water body. Previous workers have mostly focused on small, research catchments, with abundant data, but of limited scope. This study aimed to expand such work to a regional or sub-continental scale. The first full length isotope survey of the Gariep River quantifies evaporation on the river and the man-made reservoirs for the first time, and proposes a technique to calculate abstraction from the river. The theoretically determined final isotope composition for an evaporating water body in the given climate lies on the empirically determined local evaporation line, validating the assumptions and inputs to the Craig-Gordon evaporation model that was used. Evaporation from the Gariep River amounts to around $20 \%$ of flow, or $40 \mathrm{~m}^{3} / \mathrm{s}$, of which about half is due to evaporation from the surface of the Gariep and Vanderkloof Reservoirs, showing the wastefulness of large surface water impoundments. This compares well with previous estimates based on evapotranspiration calculations, and equates to around 1300 GL/a of water, or about the annual water consumption of Johannesburg and Pretoria, where over 10 million people reside. Using similar evaporation calculations and applying existing transpiration estimates to a gauged length of river, the remaining quantity can be attributed to abstraction, amounting to $175 \mathrm{~L} / \mathrm{s} / \mathrm{km}$ in the lower middle reaches of the river. Given that high water demand and climate change are global problems, and with the challenges of maintaining water monitoring networks, stable isotopes are shown to be applicable over regional to national scales for modelling hydrological flows. Stable isotopes provide a complementary method to conventional flow gauging for understanding hydrology and management of large water resources, particularly in arid areas subject to significant evaporation.
\end{abstract}




\section{GRAPHICAL ABSTRACT}

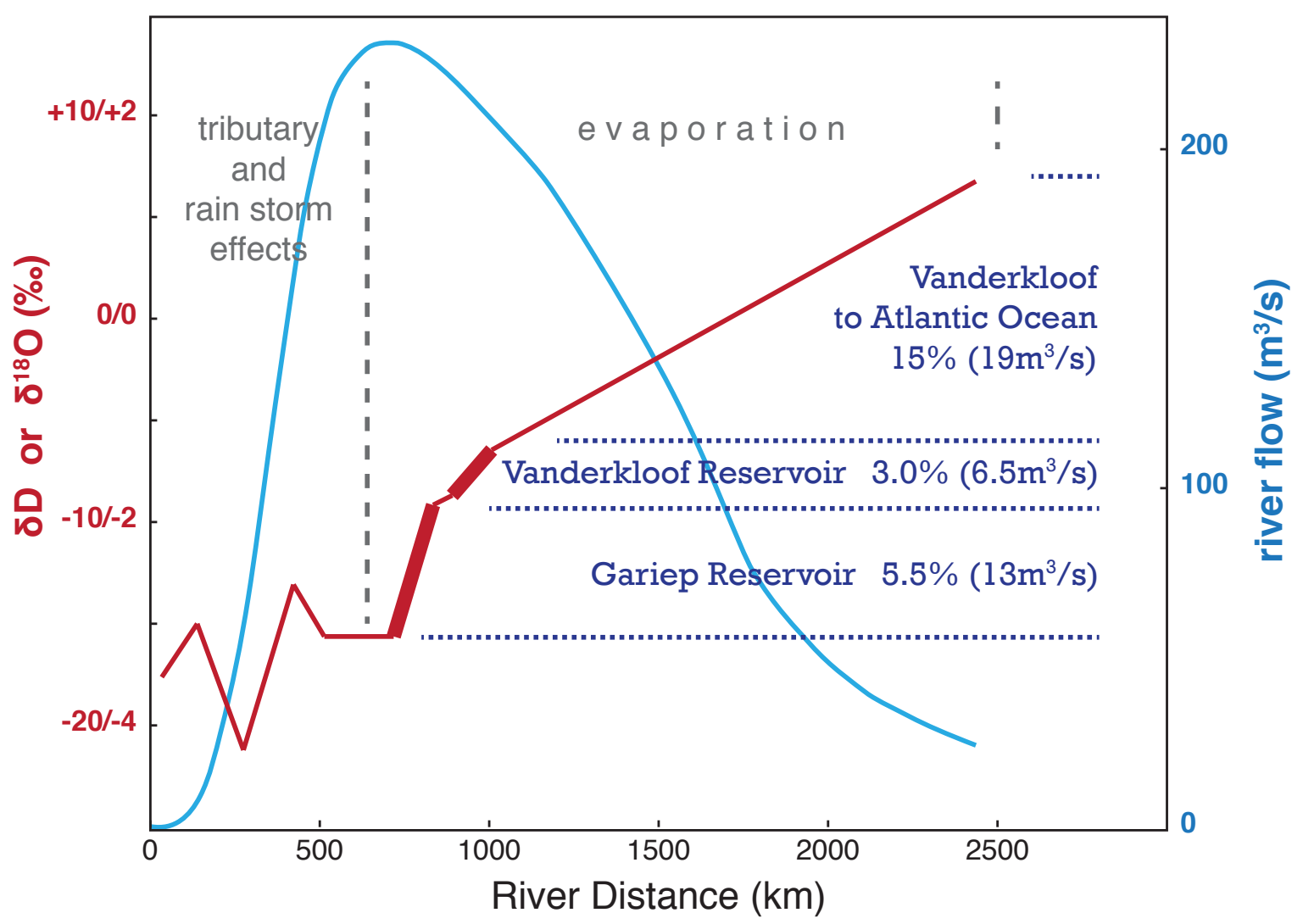

Approximate flow rate (blue curve) and stable isotope composition (red line), with evaporation, as \% of inflow for that reach of the river, determined from changes in stable isotope composition of water in the Gariep River. 


\section{Introduction}

Evaporation is one of the key flows in the global hydrological cycle, with evaporation over land averaging $60 \%$ of precipitation (Brutsaert, 1986). Evaporation, often called evapotranspiration, to include both biological transpiration and physical evaporation, comprises several components, such as physical evaporation from open water and soil, and transpiration from plants and animals. Estimates of evaporation and transpiration can be made using various methods, some of which measure evaporation or transpiration only, others of which measure a combined flux. For example, potential evaporation can be measured with pans (Shen et al., 2010); actual evaporation can be estimated with water balance models (Chen et al., 2013); transpiration can be measured in closed chamber experiments (Deguchi et al., 2008) or estimated with sap flow monitoring (Jimenez et al., 1996); evapotranspiration can be estimated with lysimeters (Wright and Harding, 1993), eddy covariance (Wever et al., 2002), satellite observations (Kalma et al., 2008), the Bowen ratio energy balance (Ma et al., 2015a) and total water budget models.

Evaporation studies are typically successful either at a small scale, where accuracy is high, but application to wider areas is limited, or cover a wide area, but are subject to more assumptions. Studies of the former type are pan evaporation, closed chamber or lysimeter measurements and research-catchment-scale water balance models, whereas studies of the latter type include remote sensing methods and regional water balance models. As pointed out by Ma et al. (2015b), most of the direct measurement methods require expensive instrumentation and expert labour, and most of the remote sensing methods provide only instantaneous evapotranspiration values. Water balance models for the Gariep River system are run by consultants on behalf of the national Department of Water \& Sanitation in South Africa every few years, but the evaporation components are not given in the various technical reports issued as part of these studies (ORASECOM, 2007; Department of Water Affairs, 2013).

Stable isotopes of water $(\mathrm{O}$ and $\mathrm{H})$ are used to answer many hydrological questions, including recharge estimation (Midgley and Scott, 1994), source delineation (Diamond and Harris, 2000) and mixing relations (Krouse and McKay, 1971). In addition to all the evaporation measurement techniques listed above, stable isotopes can also be used to calculate evaporation fractions from water bodies. This has traditionally been done at a local catchment scale, therefore falling into the category of higher accuracy, but limited application (e.g. Gammons et al., 2006; Cartwright et al., 2009; Biggs et al., 2015). Thus far, although some studies are extensive over time (Gibson and Reid, 2014), most studies have concentrated on small hydrological 
systems and few continental scale projects, such as Jasechko et al. (2013) have been conducted to demonstrate the applicability of the evaporation model on a large geographic scale and its value for understanding large water resources. In particular, the focus on calculating evaporation fractions using only stable isotopes for a single large river has not been done before, certainly not with a single, relatively small dataset. This paper aims to demonstrate the use of stable isotopes on a regional scale, showing how their application can be used to solve scientific enquiries and inform national water resource management decisions.

\subsection{Study Motivation}

South Africa is a dry country, receiving an average of around $450 \mathrm{~mm} / \mathrm{a}$ (Dent et al., 1989), barely over half of the global land average rainfall of $750 \mathrm{~mm} / \mathrm{a}$ (Oki and Kanae, 2006). In addition to 2015 and 2016 being progressively the warmest years on record (National Oceanographic and Atmospheric Administration, 2015), South Africa is experiencing the worst drought for over 20 years (van Vuuren, 2015), as a result of the recent El Niño conditions (Dai and Wigley, 2000) and exascerbated by anthropogenic climate change (Hewitson and Crane, 2006). Water restrictions are being implemented countrywide as many reservoirs are below normal levels (Department of Water and Sanitation, 2015a).

The Gariep River (or Senqu in Lesotho), formerly known as the Orange, is the largest and most economically important river in South Africa. It is an artery of water supporting agriculture, directly and via interbasin transfers and irrigation schemes, mining, hydroelectricity generation and many towns along its course. As the tributaries along the last $1200 \mathrm{~km}$ are mostly dry, evaporation has a major impact on the water resource. Calculating evaporation losses directly from differences in flow between two points is not possible, due to abstraction from the above-mentioned users and changes in flow due to variable dam releases, tributary inputs and minor flows such as from waste water treatment works and mine dewatering. There are also limitations on accuracy of gauging low flows, and small changes in flow on large rivers. Furthermore, existing gauging stations are few and their maintenance and operation has been declining over the last couple of decades, posing similar challenges to certain parts of the world (Ma et al., 2015b). Evaporation losses from the Gariep have been evaluated previously, but only theoretically, using pan evaporation values, river surface areas and transpiration estimates for riparian vegetation (McKenzie and Craig, 2001). Values from 8\%-37\% were calculated, depending on river flow, which changes the surface area to volume ratio, and transit time. Stable isotopes of water present a way of calculating evaporation losses based on actual measurements 
of the isotopic composition of the river water. This paper presents a successful new approach to measuring evaporation from a large river that can be repeated in more detail for the Gariep system, as well as applied internationally on other rivers, especially those in arid areas.

\subsection{Study Objectives}

This paper makes use of the changes in stable isotope composition of river water to do the following:

1. validate assumptions and inputs to the Craig-Gordon evaporation model used in this study

2. demonstrate the calculation of tributary flow rates and downstream isotope compositions through mass-balance calculations

3. calculate the fraction and the volume of water evaporated from the Gariep River and the two large reservoirs, Gariep and Vanderkloof

4. calculate the amount of abstraction from the river.

The overall objective of this work is to use the Gariep River as a case study to prove the viability of stable isotopes as a hydrological modelling technique for large water resources.

\section{Study Area}

The study area is shown in the map in Figure 1. Being a very large area with much natural diversity, this section is synoptic rather than comprehensive.

\subsection{Geology}

The Gariep River catchment has diverse geology, from the Archaean to Quaternary (Johnson et al., 2006). The catchment can be broadly split into three portions. First is the Karoo Supergroup that underlies the upper and middle reaches of the Gariep, Vaal and Senqu Rivers. This is a foreland basin filled with glacial deposits of the Carboniferous Dwyka Group, through deep to shallow marine sediments of the Permian Ecca Group, fluvials of the Permo-Triassic Beaufort Group, increasingly arid-environment deposits of the Triassic Stormberg Group and finally the 180Ma continental flood basalts of the Drakensberg Group, which currently underlie most of Lesotho, and have swarmed dykes and sills into much of the main Karoo Basin, through all the underlying formations. Second is the Cainozoic Kalahari Group, mostly comprising unconsolidated sands, that underlie the Molopo sub-catchment. Third are the basement rocks that 


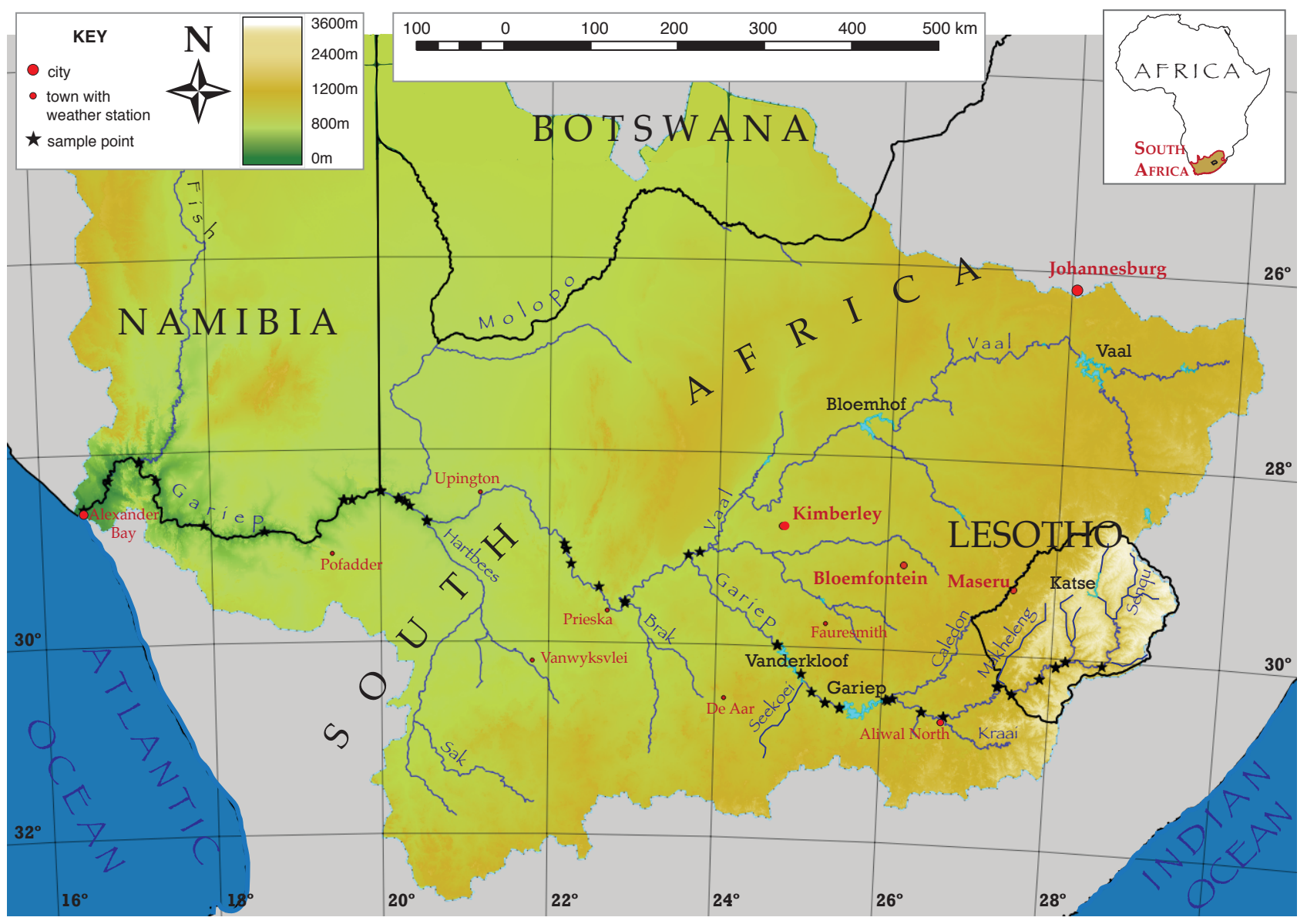

Figure 1: Map of the study area, showing the Gariep River within its watershed, major tributaries and reservoirs, towns where weather data was collected and sample sites. 
underlie the lower Vaal, and middle to lower Gariep catchment, as well as the Fish in Namibia. These comprise a wide range from the lavas of the neo-Archaen Ventersdorp Supergroup, the siliciclastics, carbonates and iron and manganese formations of the paleo-Proterozoic Transvaal Supergroup, granitoids, gneisses and metamorphics of the meso-Proterozoic Namakwa-Natal Metamorphic Province, various metamorphics of the Damara and Gariep Supergroups, the sedimentary succession of the Nama Group and various other lesser stratigraphic units.

\subsection{Geomorphology}

The landscapes of the Gariep catchment can be broadly split into four zones: Lesotho; the grasslands; the Kalahari; the Karoo and Namibia. The first is the high altitude (1500-3500m), hilly and mountainous area within and proximal to Lesotho, where the Caledon and Senqu catchments lie, and underlain by Drakensberg and Stormberg Groups. The second is the moderate altitude (1000-1800m), flat grasslands with gentle slopes, where the Vaal and upper Gariep Rivers flow, mostly underlain by Beaufort Group and some Archaean basement rocks. The third is the moderate altitude (around 1000m), flat terrain with sand dunes of the Kalahari Desert, where the Molopo catchment lies, and underlain largely by Kalahari Group sediments. The last area is highly variable, ranging from sea level to $1800 \mathrm{~m}$, including rugged mountains of the Fish River Canyon and Karoo dolerite mesas as well as large pans within the Sak River catchment, where the Hartbees, Fish (in Namibia) and lower Gariep Rivers flow, and is underlain by Proterozoic to Cainozoic rocks.

\subsection{Climate}

The Gariep catchment experiences a wide range of climates (Preston-Whyte and Tyson, 1988). Temperatures are generally mild, although summer daytime maxima are almost always over $40^{\circ} \mathrm{C}$ in the lower Gariep canyon, and winter nighttime minima reach below $0^{\circ} \mathrm{C}$ across most of Lesotho. Typically however, the mean annual temperature of towns in the Gariep catchment is around $15-21^{\circ} \mathrm{C}$ (see Table 1), following a general trend of increase westward, due primarily to dropping elevation. There is a broad increase in rainfall eastwards, towards the source of moisture, the Indian Ocean (Figure 2). On top of this broad trend is the orographic effect, where mountains receive more rainfall. Mean annual precipitation varies from almost zero at the mouth of the Gariep River, to around $1000 \mathrm{~mm} / \mathrm{a}$ at the source of the Senqu. Rainfall is largely in summer (October to April) and generally convective (thunderstorms) in nature, although further east extended periods of light rain and drizzle can result from strong advection 
off the Indian Ocean. Rare, light winter rain and snow (on the high ground) occur when large cold fronts sweep the country from the Atlantic Ocean. Of importance for understanding kinetic isotope fractionation is the relative humidity. The area is typically dry with the mean relative humidity in towns near to the Gariep River being $40-45 \%$, with a gentle trend of increasing relative humidity eastwards. The very high relative humidity at Alexander Bay is caused by regular oceanic fogs that generally only penetrate a few kilometres inland.

The stable isotope compositions of rainfall around South Africa are not well known. The two IAEA GNIP (International Atomic Energy Agency, Global Network of Isotopes in Precipitation) stations at Cape Town and Pretoria have remarkably similar long term isotope averages $(\delta \mathrm{D}$ and $\delta^{18} \mathrm{O}$ of $-8.9 \%$ and $-2.81 \%$ for Cape Town, and $-9.2 \%$ ond $-2.57 \%$ similarly for Pretoria (Rozanski et al., 1993)) given that they are climatically and geographically different in many ways. Cape Town receives winter rainfall from frontal mid-latitude depressions originating in the south Atlantic Ocean and is a coastal city, whereas Pretoria receives summer rain from thunderstorms where the moisture originates in the Indian Ocean, and is located at $1400 \mathrm{~m}$ above sea level and $500 \mathrm{~km}$ from the nearest coast. Both of these stations fall outside the Gariep catchment. Precipitation isotopes will vary substantially because of altitude, desert climate and other effects in the Gariep catchment, but the only data is from a few isolated studies, such as Vogel and van Urk (1975).

TABLE 1: Climate data for towns close to, or on the Gariep River, for 1990-2014. Locations are shown in Figure 1. The standard deviations are calculated from the monthly means. Data courtesy of the South African Weather Service. 


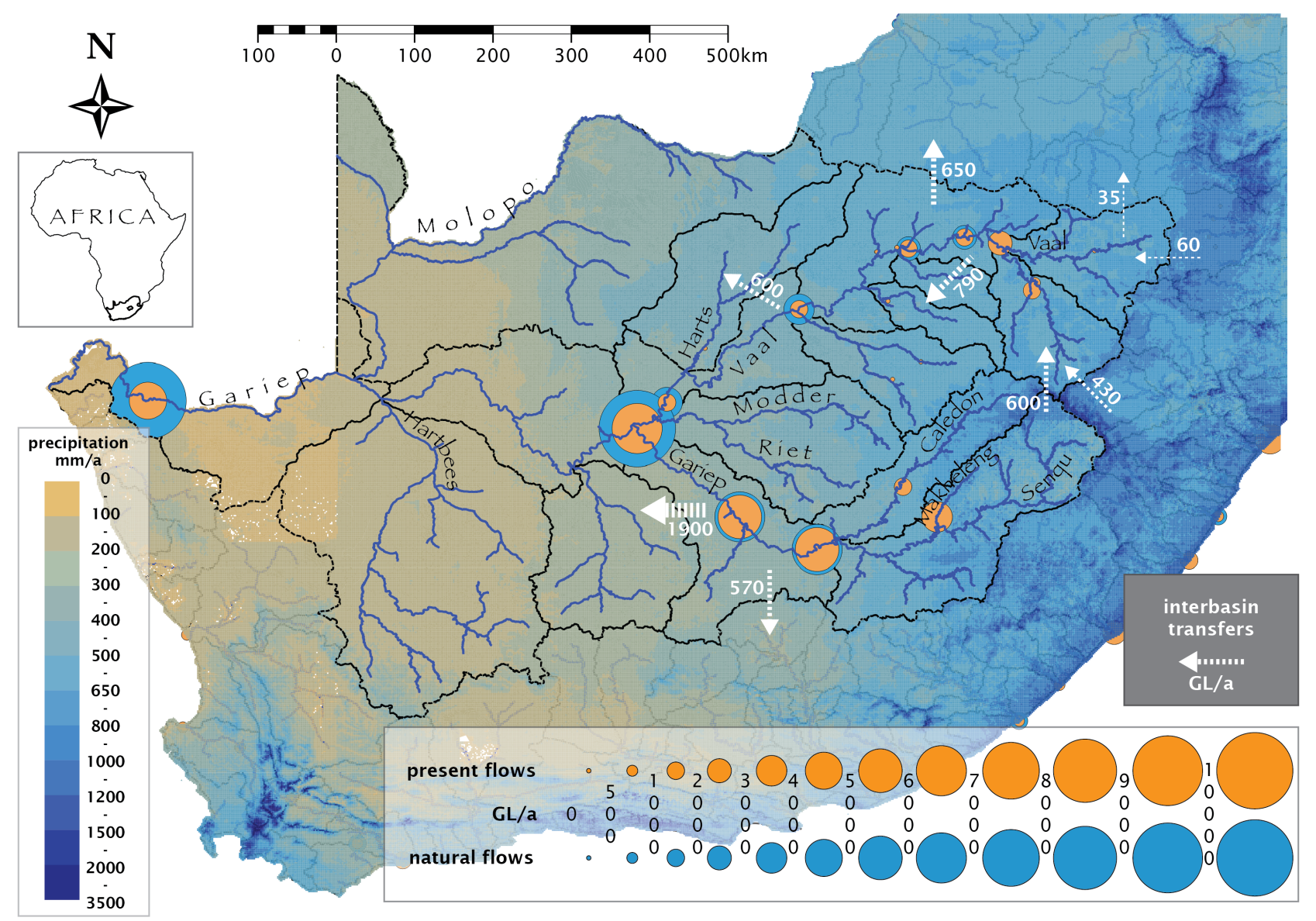

Figure 2: Mean annual precipitation for South Africa, with river flows in the Gariep system shown as both original or natural flows (blue) and current or modified flows (orange) at various gauging stations. Interbasin transfers (above 20GL/a) shown as dashed arrows. The extensively modified nature of the river system is evident from the difference in natural and current flows, as well as the abundant water transfers. The lack of any substantial input from any tributaries downstream of the Vaal River should also be clear. Precipitation data from Water Research Commission (2016). Flow and transfer data from Department of Water Affairs (2013).

\begin{tabular}{lc|cc|cc}
\multirow{2}{*}{ station } & elevation & \multicolumn{2}{|c|}{ relative humidity (\%) } & \multicolumn{2}{|c}{ temperature ( } \\
& $\mathrm{m}$ & mean & std dev & mean & std dev \\
\hline Aliwal North & 1340 & - & - & 15.5 & 5.5 \\
Fauresmith & 1360 & 46 & 9.3 & 16.2 & 5.8 \\
De Aar & 1250 & 44 & 7.6 & 17.4 & 5.4 \\
Prieska & 940 & 44 & 9.6 & 20.1 & 6.3 \\
Vanwyksvlei & 960 & 39 & 8.8 & 18.9 & 6.1 \\
Upington & 800 & 35 & 7.2 & 21.1 & 5.8 \\
Pofadder & 990 & 41 & 6.5 & 19.4 & 5.3 \\
Alexander Bay & 10 & 71 & 3.0 & 17.4 & 1.9
\end{tabular}




\subsection{Hydrogeology}

The descriptions of geology, geomorphology and climate above serve as an introduction to the complexity of the groundwater resources in the Gariep catchment. The 1:500 000 hydrogeological map series covering South Africa, published by the Department of Water Affairs, summarize the groundwater prospects of the country, including most of the Gariep catchment (e.g. Department of Water Affairs and Forestry, 2003). Borehole yields for successful boreholes (not dry) are mostly less than $2 \mathrm{~L} / \mathrm{s}$ through the Gariep catchment, with exceptions in areas of deep Kalahari sand, alluvium and a few other instances. However, these yields are not likely to be sustainable for constant pumping, considering the combination of low rainfall, low humidity and high temperatures causing high evaporation, and therefore infrequent recharge. Recharge is thought to take place only during heavy rainfall events, based on the isotopically depleted character of groundwater relative to rainfall (Vogel and van Urk, 1975). The contribution of groundwater to baseflow of the Gariep River has not been quantified, but is likely to be insignificant in the lower portions of the catchment (below the Gariep Dam) given the climate and geology. As summarized fairly well in ORASECOM (2007, p102) "The groundwater resources are somewhat limited in some areas and largely undefined within the basin."

\subsection{Hydrology}

The Gariep River is nearly $2500 \mathrm{~km}$ long and drains a catchment of around $1000000 \mathrm{~km}^{2}$, including half of South Africa, substantial areas of Namibia and Botswana, and practically the whole of Lesotho (Moolman, 1946). This makes it the 5th largest river basin in Africa and the 22nd largest in the world. The Senqu River originates at 3200 m elevation in the uKathlamba (Drakensberg) mountains in Lesotho, where rainfall is around $1000 \mathrm{~mm} / \mathrm{a}$, and the Gariep River reaches the Atlantic Ocean in the Richtersveld desert, where rainfall is less than 50 mm/a.

The hydrology of the river is complicated in several ways. Firstly, the catchment varies from high rainfall, mountainous areas to the east, far inland, around Lesotho, where the sources of the river and main tributaries lie, to much flatter, very hot and dry areas to the west where vast catchments contribute almost nothing to the main stream (Figure 3). The flatness and presence of deep sands in the Molopo catchment prevent any water from flowing out of this catchment, at least not on a regular basis: "The Molopo and Nossob Rivers in Nambia, Botswana and the Northern Cape Province have not contributed to the Orange River in recorded history as the stream bed is impeded by sand dunes;" (Department of Water Affairs, 2013, p.3). Similarly, the Sak River, which feeds into the Hartbees (Figure 1) flows regularly, but seldom contributes to 
the Gariep because of large pans above the confluence with the Hartbees that absorb all but the heaviest flows. The mean annual runoff (MAR) amounts shown in Figure 3 are theoretical and not realised in most of the drier catchments due to damming and other abstractions.

Secondly, the weather varies from year to year, and so river flows change dramatically depending on the rainfall. The hydrographs in Figure 4 show the much higher flows in certain years, although to an extent this is due to the third complication. This is that the river has been dammed substantially, with storage of large, in-stream reservoirs (i.e. excluding all the many small farm and municipal reservoirs) being 18900 GL (Department of Water and Sanitation, 2015c), almost twice the MAR of 11000 GL (Bremner et al., 1990). The effect of all these large reservoirs is that river flows are much reduced from natural flows, as seen by the orange and blue circles in Figure 2. The last complicating factor is the presence of interbasin transfers, as shown in Figure 2, where it can be seen that some of these transfers are across the continental divide.

The outcome of these four factors is that there is no "normal" river flow pattern in the Gariep any more. Heavy rainfall may not reflect in higher river flows. If reservoir levels are low, high rainfall simply gets directed to filling reservoirs. Irrigation and urban/industrial demand also influence to what degree the reservoirs spill water to the downstream. Only when all reservoirs are full or nearly full, including reservoirs outside of the Gariep catchment that receive interbasin transfer water, will there be a reasonable correspondence between rainfall and flow. Flow can therefore be seen as oscillating between two types: regulated low-flows when not all reservoirs are full, and flood-flows. The regulated low-flows vary according to sets of rules that control releases to canals, irrigators, downstream users, etc. (Department of Water Affairs, 2013). The hydrographs for years 2012-2015 in Figure 4 illustrate this regulated low-flow regime. Once all reservoirs are full or nearly full, then the natural flow pattern takes over and the reservoir outflow equals inflow, as is seen for the years 2009-2011 in Figure 4.

\section{Methods}

A source-to-sea expedition was undertaken, paddling the length of the Gariep River, starting in Lesotho on 13th January 2013 and ending at the Atlantic Ocean on 16th March 2013. Water samples were taken regularly, especially at tributaries, where a pair of samples, one of the tributary and another above the confluence on the main river (Gariep), were taken. The samples were kept in sealed $5 \mathrm{ml}$ plastic vials until analysis for stable isotope composition was performed with 


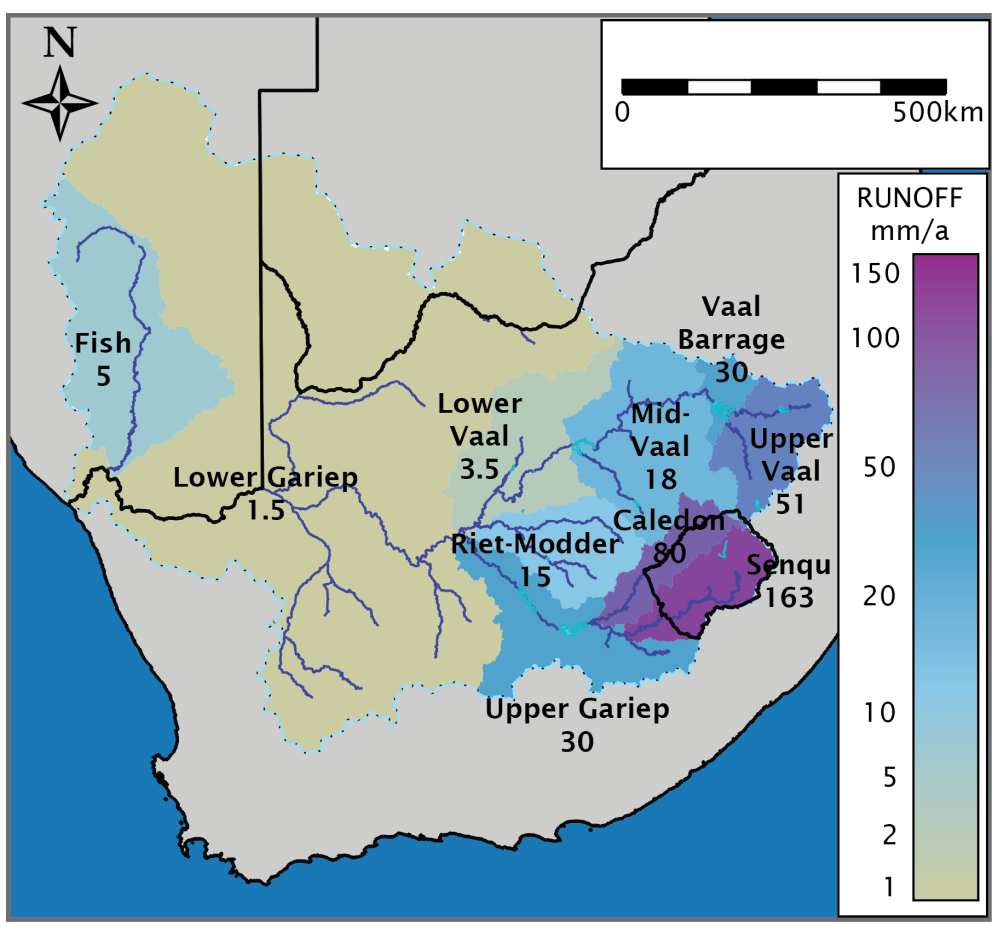

Figure 3: MAR (mean annual runoff) for the major subcatchments of the Gariep River system. The effect of higher rainfall and slope gradients and lower temperature all act together to make eastern subcatchments wetter. The Fish River has a higher runoff than the Molopo/Hartbees as the ground is higher and steeper, catching more rainfall and generating slightly more runoff. Runoff does not translate directly into flow due to impoundments, abstraction and in-stream evaporation. Data from Department of Water Affairs (2013).

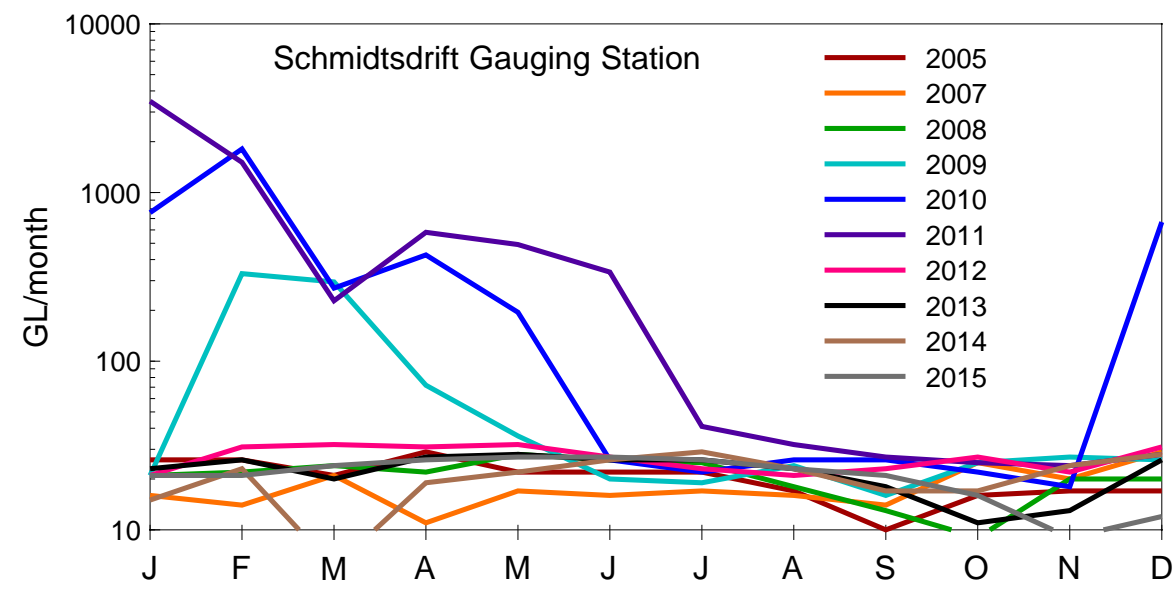

Figure 4: Hydrographs for Schmidtsdrift on the lower Vaal River for the last ten years (missing data for 2006). Flow can be seen to fall into two categories: regulated low-flows, when water is used for filling dams, meeting irrigation requirements, etc., and flood-flows, when all dams are full and natural flows dominate the system. The latter only occurred in the late summers (after the rainfall season) of 2009, 2010 and 2011. Data from Department of Water and Sanitation (2015a). 
either laser spectroscopy (West et al., 2011) or mass spectrometry (Socki et al., 1992; Schimmelman and DeNiro, 1993) at the University of Cape Town. Differences in isotope composition are depicted using the $\delta$ notation, where:

$$
\delta=\frac{R_{\text {sample }}-R_{\text {standard }}}{R_{\text {standard }}}
$$

and $\mathrm{R}$ is an isotope ratio, such as $\frac{18}{16} \mathrm{O}$. The reference standard used is SMOW (Standard Mean Ocean Water). In house reference standards CTMP-2010 (Cape Town Millipore Water 2010) and RMW (Rocky Mountain Water), with values for $\delta \mathrm{D}$ and $\delta^{18} \mathrm{O}$ of $-7.4 \%$, $-2.69 \%$ ond $-129.5 \%$, $-17.27 \%$, respectively, were used to correct for instrument drift and other laboratory errors. Laboratory precision is approximately $\pm 1 \%$ o $\delta$ and $\pm 0.2 \%$ o $\delta^{18} \mathrm{O}$. All samples analysed for $\delta \mathrm{D}$ and $\delta^{18} \mathrm{O}$ are shown on the map in Figure 1 and in Table 2. 
Table 2: Stable isotope data from the Gariep River system.

\begin{tabular}{|c|c|c|c|c|c|c|}
\hline number & $\delta \mathrm{D}$ & $\delta^{18} \mathrm{O}$ & latitude (S) & longitude (E) & elev. (m) & sample description \\
\hline I 1 & -13.1 & -2.56 & 30.05246 & 28.60823 & 1596 & Senqu \\
\hline I 2 & -14.6 & -2.50 & 30.03403 & 28.17633 & 1504 & Senqu, upstream of Senqunyane \\
\hline I 3 & -13.5 & -2.29 & 30.03210 & 28.17330 & 1504 & Senqunyane \\
\hline I 4 & -13.2 & -2.61 & 30.08919 & 28.06414 & 1497 & Senqu, upstream of Qhoali \\
\hline I 5 & -12.8 & -2.93 & 30.09053 & 28.06284 & 1497 & Qhoali \\
\hline I 6 & -10.7 & -2.50 & 30.22365 & 27.87404 & 1450 & Senqu, upstream of Quthing \\
\hline I 7 & & -2.3 & 30.22508 & 27.87592 & 1450 & Quthing \\
\hline I 8 & -13.2 & -2.38 & 30.40480 & 27.55600 & 1407 & Senqu, upstream of Tele \\
\hline I 9 & -15.9 & -2.94 & 30.40541 & 27.55562 & 1407 & Tele \\
\hline I 10 & -16.1 & -2.79 & 30.32626 & 27.37793 & 1386 & Senqu, upstream of Makheleng \\
\hline I 11 & -30.5 & -4.53 & 30.32475 & 27.37713 & 1386 & Makheleng \\
\hline I 12 & -19.2 & -3.44 & 30.66579 & 26.75226 & 1310 & Gariep, upstream of Kraai \\
\hline I 13 & -15.7 & -3.21 & 30.66811 & 26.75226 & 1309 & Kraai \\
\hline I 14 & -17.3 & -3.31 & 30.63064 & 26.48624 & 1286 & Gariep, upstream of Stormbergspruit \\
\hline I 15 & -10.7 & -1.80 & 30.63153 & 26.48629 & 1288 & Stormbergspruit \\
\hline I 16 & -19.4 & -1.88 & 30.52427 & 26.07079 & 1268 & Gariep, upstream of Caledon \\
\hline I 17 & 30.1 & 6.58 & 30.52131 & 26.05238 & 1267 & Caledon, stagnant pool \\
\hline G 1 & -20.6 & -3.82 & 30.50460 & 26.13092 & 1262 & Gariep reservoir, upper reaches \\
\hline G 2 & -6.9 & -1.81 & 30.62081 & 25.50398 & 1253 & Gariep reservoir, at wall, windy, waves \\
\hline G 3 & -9.2 & -1.96 & 30.62528 & 25.50074 & 1209 & Gariep, below reservoir \\
\hline I 18 & -8.7 & -1.88 & 30.57008 & 25.32633 & 1188 & Gariep, upstream of Oorlogspoortrivier \\
\hline I 19 & -5.0 & -0.85 & 30.57477 & 25.32713 & 1186 & Oorlogspoort \\
\hline V 1 & -10.5 & -1.97 & 30.46754 & 25.16193 & 1181 & Vanderkloof reservoir, upper reaches \\
\hline V 2 & -8.2 & -1.75 & 30.28595 & 25.03171 & 1180 & Vanderkloof reservoir, upstream of Seekoei \\
\hline V 3 & -6.7 & -1.51 & 29.99406 & 24.73985 & 1177 & Vanderkloof reservoir, at wall \\
\hline V 4 & -7.7 & -1.66 & 29.99123 & 24.72654 & 1100 & Gariep, below Vanderkloof \\
\hline I 20 & -6.1 & -1.36 & 29.07768 & 23.64433 & 970 & Gariep, upstream of Vaal \\
\hline I 21 & 2.1 & 0.78 & 29.04893 & 23.77849 & 933 & Vaal \\
\hline I 22 & -4.4 & -0.98 & 29.57587 & 22.90914 & 929 & Gariep, upstream of Brak \\
\hline I 23 & -4.5 & -0.62 & 29.58890 & 22.90617 & 928 & Brak \\
\hline I 24 & -7.0 & -0.96 & 29.42950 & 22.59733 & 910 & Gariep \\
\hline B 1 & -4.4 & -1.01 & 29.18471 & 22.25468 & 879 & Boegoeberg reservoir, upper reaches \\
\hline B 2 & -3.5 & -1.04 & 29.04447 & 22.19929 & 887 & Boegoeberg reservoir, at wall \\
\hline В 3 & -4.1 & -0.92 & 29.04394 & 22.19927 & 877 & Gariep, below Boegoeberg \\
\hline I 25 & -4.7 & -0.77 & 28.97559 & 22.18037 & 870 & Gariep \\
\hline I 26 & -0.7 & -0.91 & 28.74906 & 20.54896 & 640 & Gariep, upstream of Hartbees \\
\hline I 27 & 0.8 & -0.62 & 28.75120 & 20.54838 & 643 & Hartbees, very low flow \\
\hline I 28 & 0.9 & -0.67 & 28.59440 & 20.34448 & 620 & Gariep, above Augrabies Falls \\
\hline I 29 & 1.7 & -0.50 & 28.54671 & 20.28668 & 445 & Gariep, below Augrabies Falls \\
\hline I 30 & 0.3 & -0.25 & 28.52158 & 20.22198 & 440 & Gariep, upstream of Molopo \\
\hline I 31 & -0.7 & -0.36 & 28.51736 & 20.21172 & 433 & Gariep, downstream of Molopo (dry) \\
\hline I 32 & 1.4 & & 28.43956 & 20.01409 & 428 & Gariep, upstream of Loeriesfontein \\
\hline I 33 & 8.5 & 1.94 & 28.43427 & 20.01159 & 433 & Loeriesfontein, stagnant pool \\
\hline I 34 & 3.0 & -0.31 & 28.52418 & 19.67353 & 407 & Gariep, upstream of Yas se Laagte (dry) \\
\hline I 35 & 1.7 & & 28.53068 & 19.57832 & 410 & Gariep, upstream of Kaibab (dry) \\
\hline I 36 & 1.7 & -0.21 & 28.52985 & 19.56498 & 407 & Gariep, upstream of Ham (dry) \\
\hline I 37 & 2.0 & 0.24 & 28.84245 & 18.63330 & 230 & Gariep, upstream of Houm (dry) \\
\hline I 38 & 3.2 & 0.43 & 28.76676 & 17.91731 & 181 & Gariep, upstream of Haib (dry) \\
\hline I 39 & 4.8 & 0.39 & 28.28261 & 17.37205 & 109 & Gariep, upstream of Gamkab (dry) \\
\hline I 40 & 4.9 & -0.18 & 28.10079 & 17.18173 & 66 & Gariep, upstream of Fish \\
\hline I 41 & 25.0 & 6.49 & 28.09445 & 17.17301 & 65 & Fish River, stagnant pool \\
\hline I 42 & 5.9 & 1.09 & 28.27600 & 16.79831 & 22 & Gariep, $75 \mathrm{~km}$ from Atlantic \\
\hline I 43 & 7.7 & 1.13 & 28.56683 & 16.50283 & 8 & Gariep, $10 \mathrm{~km}$ from Atlantic \\
\hline
\end{tabular}




\subsection{Validation of Stable Isotope Evaporation Model}

A theoretical model for the evolution of isotope composition of water during evaporation from the ocean surface has been developed (Craig and Gordon, 1965). This model has been improved and modified over the years, including determination of the optimal input parameters (Zuber, 1983; Horita and Weslowski, 1994; Gat, 1995), and applied in hydrological studies, mostly looking at the water balance on lakes (Dinçer, 1968; Gibson et al., 2002; Mayr et al., 2007). Recent uses of the technique have included detailed evaporation fraction calculations (Biggs et al., 2015) and a programme to allow calculation of evaporative losses (Skrzypek et al., 2015). As much as methodological work remains to be done on the evaporation model, this paper aims, amongst other things, to show that the implementation of the model appears to be valid. The model is described in the following set of equations.

The model is developed on the premise of an open system under dynamic equilibrium, in which:

$$
Q=I-E,
$$

where $\mathrm{Q}$ is the outflow, I is the inflow and $\mathrm{E}$ is the evaporation from the water body.

The water is assumed to have no dissolved constituents, as they occur mostly in minor quantities in typical continental fresh water settings. Dissolved salts would reduce the evaporation rate and increase fractionation between liquid and vapour. The model set up also simplifies the atmosphere into a two layer system, where the lower layer in contact with the water body moves water vapour by molecular diffusion, and the upper layer moves water by eddy turbulence. In reality there would more likely be a gradient from mainly molecular diffusion above the water surface to mostly dispersion by eddy turbulence at higher altitude. Furthermore, this turbulent layer is assumed to be non-fractionating because all isotopic species are assumed to have the same turbulent resistance (Craig and Gordon, 1965).

The amount of water evaporated (E) relative to the inflow (I) of water into a water body is a dimensionless fraction and is calculated by:

$$
\frac{E}{I}=\frac{\delta_{L}-\delta_{I}}{m\left(\delta^{*}-\delta_{L}\right)}
$$

where $\delta_{L}$ is the isotope composition (\%o) in the water body after evaporation, $\delta_{I}$ is the isotope composition (\%o) of all water flowing into the system (including ground, surface and rain water), $\delta^{*}$ is the theoretical final isotope composition (\%o) of an evaporated water body in the field area 
and $m$ is known as the enrichment factor. This factor is calculated as:

$$
m=\frac{h-0.001 \varepsilon}{1-h+0.001 \varepsilon_{K}}
$$

where $\mathrm{h}$ is relative humidity of air above the water (as a fraction, $0-1$ ), $\varepsilon$ is the total fractionation, summed as follows:

$$
\varepsilon=\varepsilon_{*}+\varepsilon_{K}
$$

where $\varepsilon_{*}$ is the equilibrium fractionation factor between liquid and vapour (dimensionless number), and $\varepsilon_{K}$ the kinetic fractionation factor (dimensionless number). Equilibrium isotope fractionation factors were calculated from two previous studies (Chacko et al., 2001), (Kakiuchi and Matsuo, 1979; Beaudoin and Therrien, 2014) and an average was taken between these, although there was only a difference of $0.6 \%$ for hydrogen and $0.08 \%$ for oxygen in the final E/I result by using the two different fractionation factors. The kinetic fractionation factor is calculated by:

$$
\varepsilon_{K}=C_{K}(1-h)
$$

where $\mathrm{C}_{K}$ was measured as $12.5 \%$ for $\delta \mathrm{D}$ and $14.2 \%$ for $\delta^{18} \mathrm{O}$ (Gonfiantini, 1986). The final isotope composition of an evaporating water body is calculated as:

$$
\delta^{*}=\frac{h . \delta_{A}+\varepsilon}{h-0.001 \varepsilon}
$$

where $\delta_{A}$ is the isotope composition (\%o) of water vapour in the atmosphere above the evaporating water body, estimated by:

$$
\delta_{A}=\delta_{P}-\varepsilon_{*},
$$

where $\delta_{P}$ is the typical isotope composition of precipitation (\%o) in the region, and can be approximated as $\delta_{I}$. The above equation is developed on the grounds that the atmospheric vapour over the water body is in isotopic equilibrium with the precipitation of the region (Craig and Gordon, 1965).

It has been noted for arid or seasonal climates that equation 8 can be adjusted to:

$$
\delta_{A}=\frac{\left(\delta_{P}-k \varepsilon_{*}\right)}{\left(1+10^{-3} k \varepsilon_{*}\right)}
$$

where $\mathrm{k}$ is a factor to adjust for non-equilibrium between precipitation and atmospheric vapour, and has values from around 0.5 for highly seasonal climates to around 1 for non-seasonal 
climates (Gibson et al., 2016). The climate in the Gariep catchment is moderately seasonal. Temperatures vary by $10^{\circ} \mathrm{C}$ between winter and summer; more specifically, mean daily temperatures in the eastern part of the catchment are $10-20^{\circ} \mathrm{C}$ for winter (April to September) and summer (October to March), and for the western part of the catchment $15-25^{\circ} \mathrm{C}$ similarly. Relative humidity (h) varies by $10 \%$; more specifically $50 \%$ in winter to $40 \%$ in summer.

The validation of the model as it was implemented for this study was performed by comparing the theoretically calculated final isotope composition of an evaporating water body $\left(\delta^{*}\right)$ with the experimentally calculated local evaporation line (LEL) based on measurements of the isotopic composition of varyingly evaporated water bodies. The point $\delta^{*}$ should plot on, or very close to, the LEL, if the model equations and input parameters, such as equilibrium and kinetic isotope fractionation factors, mean relative humidity and mean air temperature, are correct.

\subsection{Mass Balance Calculations}

A standard mass balance approach may be applied to the isotope compositions in water, according to the formula:

$$
\delta_{G f}=\left(\delta_{G i} \times \frac{Q_{G i}}{Q_{G f}}\right)+\left(\delta_{t r i b} \times \frac{Q_{t r i b}}{Q_{G f}}\right)
$$

where $\delta$ are isotope values and Q are flow rates, and where Gi indicates "Gariep initial" (upstream of the confluence), Gf indicates "Gariep final" (downstream of the confluence) and "trib" indicates a tributary). Note that this method is performed over a short stretch of river, typically less than $100 \mathrm{~km}$, so the effect of evaporation is considered negligible and has therefore been left out of the equation as a term. In the situation where the only significant flow added to the river between the upstream $\left(\mathrm{Q}_{G i}\right)$ and downstream $\left(\mathrm{Q}_{G f}\right)$ sampling points is the tributary $\left(\mathrm{Q}_{t r i b}\right)$, then:

$$
Q_{t r i b}=Q_{G f}-Q_{G i}
$$

so the mass balance formula can be rearranged to:

$$
Q_{t r i b}=Q_{G f} \times\left(\frac{\delta_{G f}-\delta_{G i}}{\delta_{t r i b}-\delta_{G i}}\right)
$$

The same approach can be used to determine the final isotopic composition of two tributaries with known flow rates and isotope compositions, where equation 10 can be rearranged to:

$$
\delta_{G f}=\delta_{G i}+\frac{Q_{t r i b}}{Q_{G f}} \times\left(\delta_{t r i b}-\delta_{G i}\right)
$$




\subsection{Evaporation Calculations}

The stable isotope evaporation model was described in the section above on model validation. Table 3 outlines the various parameters and the sources of data used in the model equations.

\subsection{Abstraction Calculations}

A standard hydrological model for a river assumes that major inputs and outputs are in dynamic equilibrium, allowing the establishment of a water balance:

$$
Q_{i}+Q_{t r i b}+g w_{d i s}+P=Q_{f}+g w_{r e c h}+E T+A b
$$

where $\mathrm{Q}_{i}$ is the initial river flow upstream of the area of interest, $\mathrm{Q}_{t r i b}$ is the flow of tributaries into the trunk stream, $\mathrm{gw}_{\text {dis }}$ is baseflow into the river, $\mathrm{P}$ is precipitation onto the river surface, $\mathrm{Q}_{f}$ is the final river flow downstream of the area of interest, $\mathrm{gw}_{\text {rech }}$ is loss of river water to groundwater, ET is evapotranspiration and Ab is abstraction. Some sections of the Gariep River have negligible rainfall, no tributaries of any significance and baseflow and recharge can be assumed to be negligible, based on the low gradient landscape, low rainfall climate and hard rock geology with no major aquifers (Woodford and Chevallier, 2002; Vegter, 2006), as outlined previously in Sections 2.3 to 2.4. The water balance can then be rewritten as:

$$
Q_{i}=Q_{f}+E T+A b
$$

\section{Results}

Fifty-three samples of river water were analysed for their hydrogen and oxygen stable isotope content, of which 39 were from the Gariep River and 14 from tributaries. On the Gariep River trunk stream, samples included water in the Gariep, Vanderkloof and Boegoeberg Reservoirs, and of the tributaries, the streams sampled varied from strongly flowing to stagnant pools. All the data is plotted on Figure 5, where tributaries and the main river are given different symbols and have had different best-fit lines calculated, according to the structural regression method, where both $\mathrm{x}$ and $\mathrm{y}$ are independent variables.

The isotope data for the Gariep River main stream defines a best-fit line with similar gradient to the Cape Meteoric Water Line (Diamond and Harris, 1997). Although the Cape experiences winter rainfall and the Gariep catchment summer rainfall, temperature and humidity conditions 
are similar enough across the subcontinent that MWLs should be similar (Liu et al., 2010). The lower $\delta \mathrm{D}$-intercept for the Gariep River best-fit line is probably caused by evaporation in various catchment processes, including during rainfall and river flow.

Mean air temperature (T) and relative humidity (h) were calculated from the South African Weather Service stations shown on the map in Figure 1, and summarised in Table 1.

\subsection{Validation of Stable Isotope Evaporation Model}

The tributaries best-fit line is a proxy for a local evaporation line (LEL), as it has samples from unevaporated, strongly flowing rivers (e.g. Senqunyane, Tele) through slow flowing rivers that have experienced some evaporation (e.g. Vaal), to highly evaporated, almost stagnant pools (e.g. Fish). The data used to calculate this line is only the stable isotope ratios of $\mathrm{H}$ and $\mathrm{O}$ from the water samples.

As seen in the lower inset in Figure $5, \delta_{A}$ was calculated with no correction according to Equation $8(\mathrm{k}=1)$, and with the most substantial correction factor of $\mathrm{k}=0.5$ according to Equation 9. The latter result does bring the value for $\delta_{A}$ closer to the Gariep River MWL and the Tributaries MWL (the LEL), but does not sit on the LEL and has used an overly severe correction factor of 0.5 for the climate that is only moderately seasonal, with winter to summer differences of $10^{\circ} \mathrm{C}$ and $10 \%$ relative humidity. Based on the unconvincing performance of this correction factor and the evidence presented below, it was not utilized in the main calculations of evaporation percentages for the Gariep River and reservoirs.

Based on the equations presented in the Methods section above, the theoretically calculated values of $\delta^{*}$, the final isotope composition of an evaporating water body, are $+138 \%$ o and $+28.3 \%$ for $\delta \mathrm{D}$ and $\delta^{18} \mathrm{O}$, for the given climatic and isotopic conditions of this study. The calculation of $\delta^{*}$ is according to Equation 7 and uses the following inputs: measured parameters from this study for $\mathrm{T}, \mathrm{h}$, and $\delta_{I}$; measured parameters from Chacko et al. (2001), Kakiuchi and Matsuo (1979) and Beaudoin and Therrien (2014) for $\varepsilon_{*}$; measured parameters from Gonfiantini (1986) for $C_{K}$; calculated parameters using data from this study for $\varepsilon_{K}$; and calculated parameters from this and the previously cited studies for $\delta_{A}$. There is no overlap between any of these seven measured or calculated parameters and the data used to generate the LEL, as the $\delta$ values used to calculate $\delta_{I}$ and $\delta_{A}$ are from the trunk stream and not the tributaries.

The near coincidence of $\delta^{*}$ and the LEL (see Figure 5 upper inset) provides confirmation of the assumptions and input values used in the evaporation model here. 


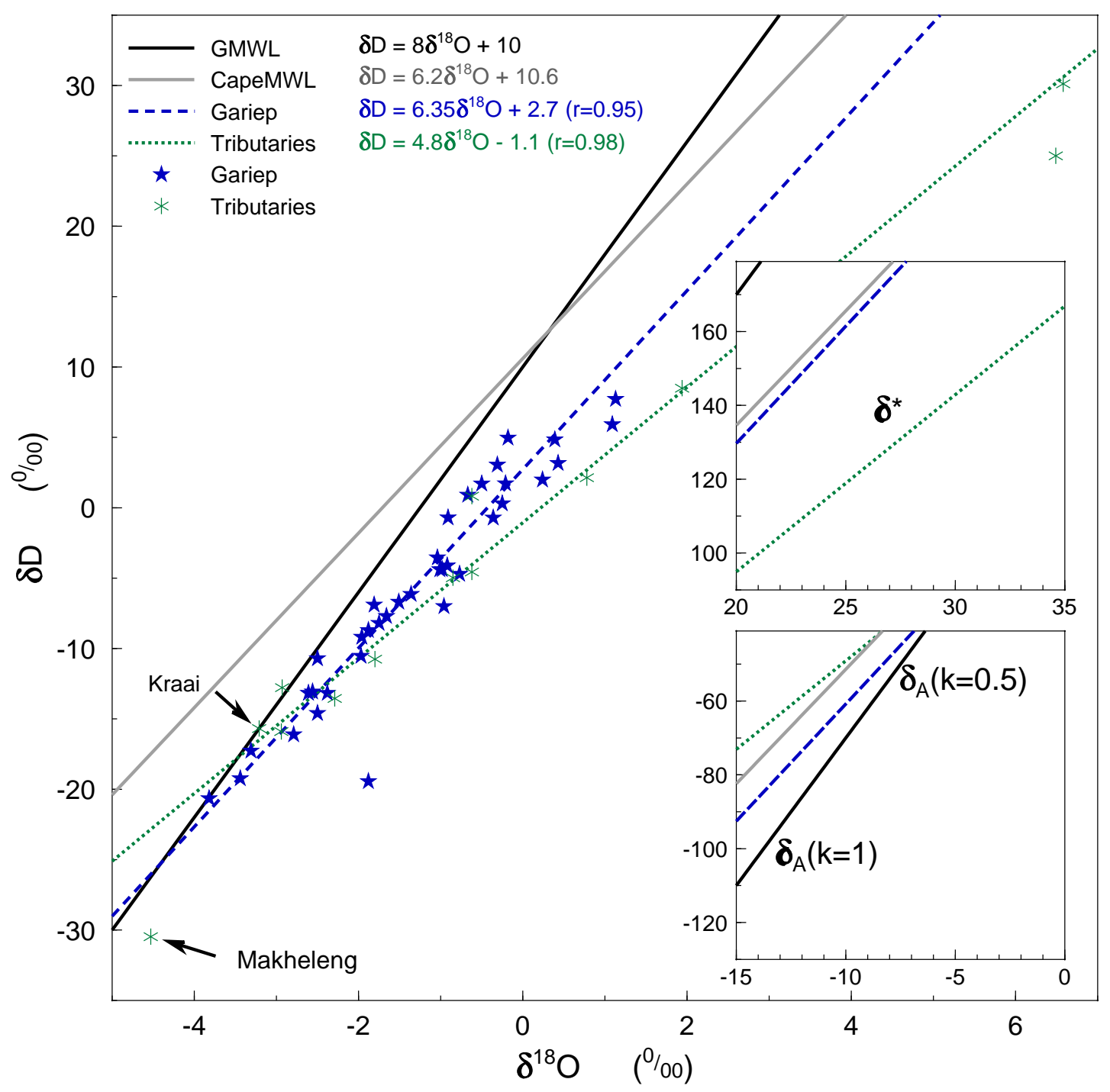

Figure 5: $\delta \mathrm{D}-\delta^{18} \mathrm{O}$ plot of all samples, comparing best-fit lines of the data, split into tributaries and the trunk stream, to the Cape Meteoric Water Line and the Global Meteoric Water Line. The inset shows extensions of the lines in the main graph and the theoretical final isotope composition of an evaporating puddle $\left(\delta^{*}\right)$. Note the proximity of the theoretical point $(+)$ to the tributaries best-fit line, which is a proxy for a local evaporation line (see main text). 


\subsection{Mass Balance Calculations}

Isotope data for the main Gariep River channel is plotted in Figure 6, while flow rates from gauging stations on the Gariep River and tributaries at the time of sampling (Department of Water and Sanitation, 2015b) are plotted in Figure 7. Mass balance was applied to determine flow on the Makheleng River as follows:

$$
\delta D: Q_{M a k}=Q_{G f} \times\left(\frac{\delta_{G f}-\delta_{G i}}{\delta_{t r i b}-\delta_{G i}}\right)=203 \times\left(\frac{(-19.2)-(-16.1)}{(-30.5)-(-16.1)}\right)=44 m^{3} / s
$$

and

$$
\delta^{18} O: Q_{M a k}=Q_{G f} \times\left(\frac{\delta_{G f}-\delta_{G i}}{\delta_{t r i b}-\delta_{G i}}\right)=203 \times\left(\frac{(-3.44)-(-2.79)}{(-4.53)-(-2.79)}\right)=75 m^{3} / s
$$

giving a mean of $60 \mathrm{~m}^{3} / \mathrm{s}$, compared to the measured flow of $52 \mathrm{~m}^{3} / \mathrm{s}$. In this situation the river flows were subject to variations in flow in the tens of percent from day to day and the Gi and Gf sample points were more than $100 \mathrm{~km}$ apart. The significance of the result in the face of such uncertainty is evaluated in the Discussion chapter, under Section 5.2.

A mass balance calculation was applied on the Vaal-Gariep confluence, to investigate the effect of the isotopically enriched (highly evaporated) water from the Vaal (I21) on the downstream isotope composition of the Gariep. The formulae and results are as follows:

$$
\delta D: \delta_{G f}=\delta_{G i}+\frac{Q_{V}}{Q_{G f}} \times\left(\delta_{V}-\delta_{G i}\right)=-6.1+\frac{10}{180} \times(2.1--6.1)=-5.7
$$

and

$$
\delta^{18} O: \delta_{G f}=\delta_{G i}+\frac{Q_{V}}{Q_{G f}} \times\left(\delta_{V}-\delta_{G i}\right)=-1.36+\frac{10}{180} \times(0.78--1.36)=-1.24
$$

These results can be compared with the $\delta_{G i}$ values (I20), giving differences of $0.4 \%$ for $\delta \mathrm{D}$ and $0.10 \%$ for $\delta^{18} O$. This is about analytical error for $\delta \mathrm{D}$ and $\delta^{18} O$ and shows that the influence of the Vaal, although having highly evaporated water, is minimal because of the low Vaal flow.

\subsection{Evaporation Calculations}

The dataset of isotope compositions collected in this study has a striking upward trend, as seen in Figure 6. This is attributed to evaporation, because neither surface water nor groundwater inputs are considered significant enough to cause this change in isotope composition downstream.

There are only 4 tributaries with any significant input downstream of the $500 \mathrm{~km}$ mark 


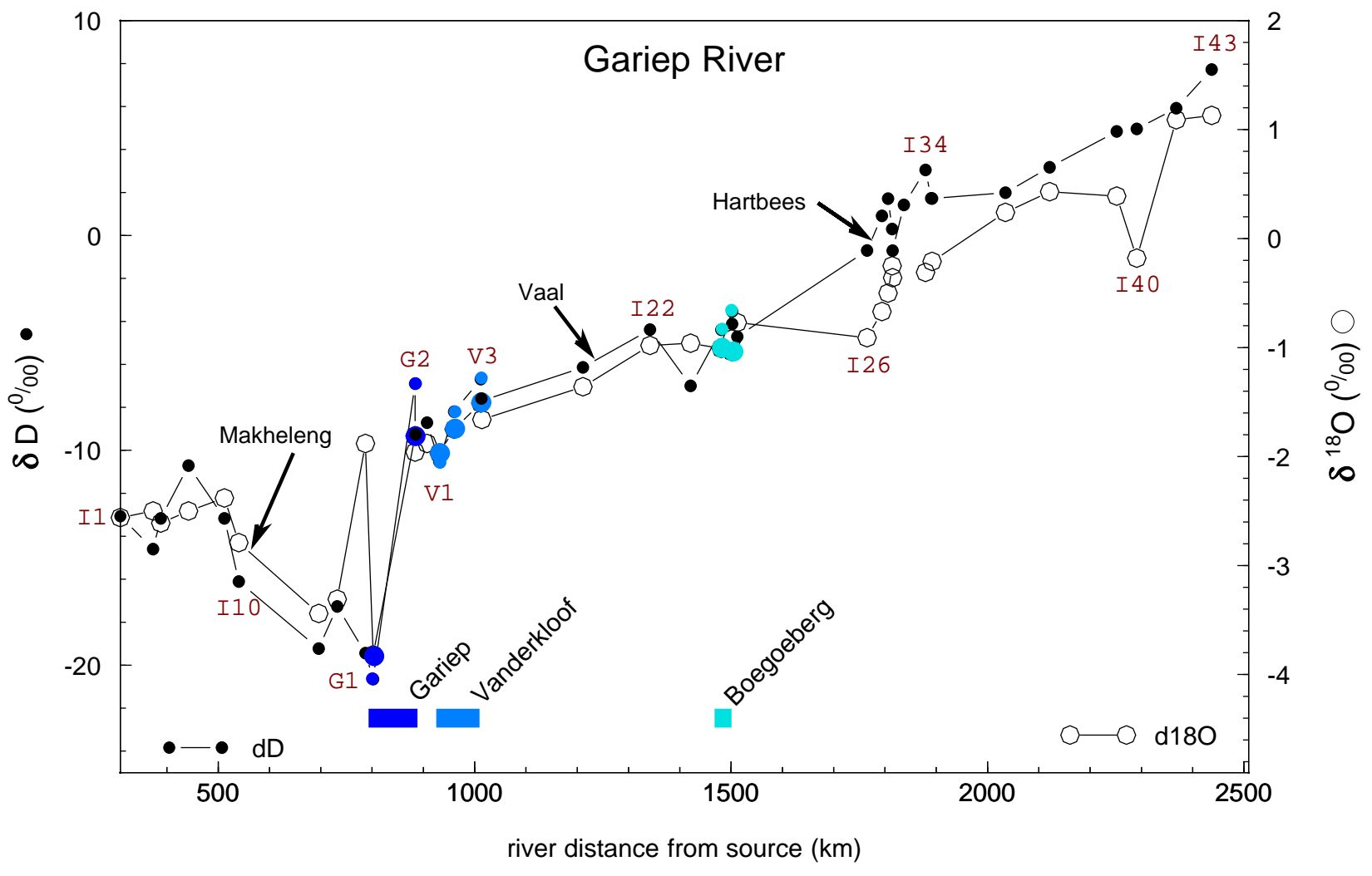

Figure 6: Isotope composition of samples from the trunk stream of the Gariep, plotted according to distance from the source. The positions of major reservoirs are marked, as is the confluence of the Makheleng River (previously known as the Kornetspruit). The rising trend in $\delta$ values is caused by evaporation. 
(approximately at the Lesotho-South Africa border): Makheleng, Kraai, Caledon and Vaal. One of the two large surface water tributaries (Kraai) has an isotope composition similar to that of the main Gariep stream (see Figures $5 \& 7$ ). The combination of similar isotope composition and minor flow input means that the overall shift in isotope composition from the input of the Kraai River will be minimal. The high flow rate (about $50 \mathrm{~m}^{3} / \mathrm{s}$ ) and very low $\delta$ values of the Makheleng (I11: $-30.0 \%$ o, $-4.53 \%$ ) make it the only river to significantly affect the isotope composition of the Gariep trunk stream, as seen by the low $\delta$ values in Figure 6 following the confluence of these two rivers. There is little input of water below the Gariep Dam, at about the $900 \mathrm{~km}$ mark, and therefore the steady increase in $\delta$ values with distance downstream from this point is attributed to evaporation.

Natural groundwater inputs are deemed inconsequential because of the dry climate, very minor alluvium and mainly hard rock geology with only fracture porosity (Woodford and Chevallier, 2002; Vegter, 2006), as outlined previously in Sections 2.3 and 2.4. Groundwater inputs from irrigation return flows are assumed to be minimal, also because of the factors above; these will tend to cause most irrigation water to be transpired or evaporate, and slow any throughflow that does occur.

\subsubsection{Gariep Reservoir}

The E/I calculation for the Gariep Reservoir using the measured isotope compositions from the most upstream and downstream (near the wall) positions yields 15\% and 9.5\% from changes in $\delta \mathrm{D}$ and $\delta^{18} \mathrm{O}$ respectively. The Makheleng River input (I11), and associated recent storm runoff from minor tributaries, affects the evaporation calculation on the Gariep Reservoir by creating anomalously low input values (G1: $-20.0 \%$, $-3.90 \%$ ). As noted in Table 2, the Makheleng was in spate after recent heavy rain and both the flow was above average and the isotope composition below that of all other tributaries. These are probably not reflective of the medium term inflowing river water and result in the anomalously high evaporation percentages calculated above. More reasonable input values $\left(\delta_{I}\right)$ would be the average of all upstream isotope compositions: $-15.2 \%$ o, $-2.67 \%$.

Although the water in the Gariep Reservoir should be well mixed by frequent strong winds, the isotope composition of released water (coming from deeper in the water column) as measured in a sample downstream of the dam wall (G3: -9.2\%o, -1.96\%o), suggests water as collected at the reservoir surface (G2: $-6.9 \%,-1.81 \%$ ) may be slightly more evaporated than the average upstream of the wall, and so the output values $\left(\delta_{L}\right)$ have been averaged to $-8.0 \%$, $-1.88 \%$. 
Rerunning the E/I calculation with the moderated input and output values yields $7.7 \%$ and $3.4 \%$ from changes in $\delta \mathrm{D}$ and $\delta^{18} \mathrm{O}$ respectively, giving a mean of 5.5\% evaporation.

\subsubsection{Vanderkloof Reservoir}

The E/I calculation for Vanderkloof Reservoir yields $4 \%$ and $2 \%$ based on changes in $\delta \mathrm{D}$ and $\delta^{18} \mathrm{O}$ respectively, with a mean of $3.0 \%$. The amount of evaporation from a reservoir should be proportional to the volume of the reservoir, as larger reservoirs have greater surface areas and longer storage times. As shown in Table 4, the Vanderkloof Reservoir (3171 GL (gigalitres)) to Gariep Reservoir (5196 GL) volume ratio is 0.61 , and the E/I results have ratios of 0.52 and 0.58 for $\delta \mathrm{D}$ and $\delta^{18} \mathrm{O}$, this confirms that evaporation conditions are similar on the two reservoirs. The surface area to volume ratio of the reservoirs will affect the relative amounts of evaporation, and as the Vanderkloof Reservoir is deeper and narrower this may account for the slightly lower E/I ratios.

Table 4: Comparison of evaporation percentages calculated from changes in stable isotope compositions flowing into and out of the two large reservoirs on the Gariep River, with their volumes, which are seen as a proxy for storage time, and therefore time available for evaporation.

\begin{tabular}{lccr} 
& $\mathrm{E} / \mathrm{I}$ from $\Delta \delta \mathrm{D}$ & $\mathrm{E} / \mathrm{I}$ from $\Delta \delta^{18} O$ & volume \\
& $\%$ & $\%$ & $\mathrm{GL}$ \\
\hline Vanderkloof Reservoir & 4.0 & 1.9 & 3171 \\
Gariep Reservoir & 7.7 & 3.4 & 5196 \\
ratio: $\frac{\text { Vanderkloof }}{\text { Gariep }}$ & 0.52 & 0.58 & 0.61
\end{tabular}

\subsubsection{Gariep River}

The E/I calculation for the length of the Gariep River takes a conservative estimate by projecting a best-fit line onto the two y-axes in Figure $6\left(\delta \mathrm{D}\right.$ on the left and $\delta^{18} \mathrm{O}$ on the right), ignoring the dip in $\delta$ values caused by the Makheleng River. This produces initial isotope compositions of $-14.0 \%$ and $-2.60 \%$ or for $\delta \mathrm{D}$ and $\delta^{18} \mathrm{O}$ respectively. The E/I results are $24.5 \%$ and $19 \%$ from $\delta \mathrm{D}$ and $\delta^{18} \mathrm{O}$. These fall in the middle of the range calculated theoretically from evaporation and transpiration estimates by McKenzie and Craig (2001), which ranged from 8-37\% for low to 


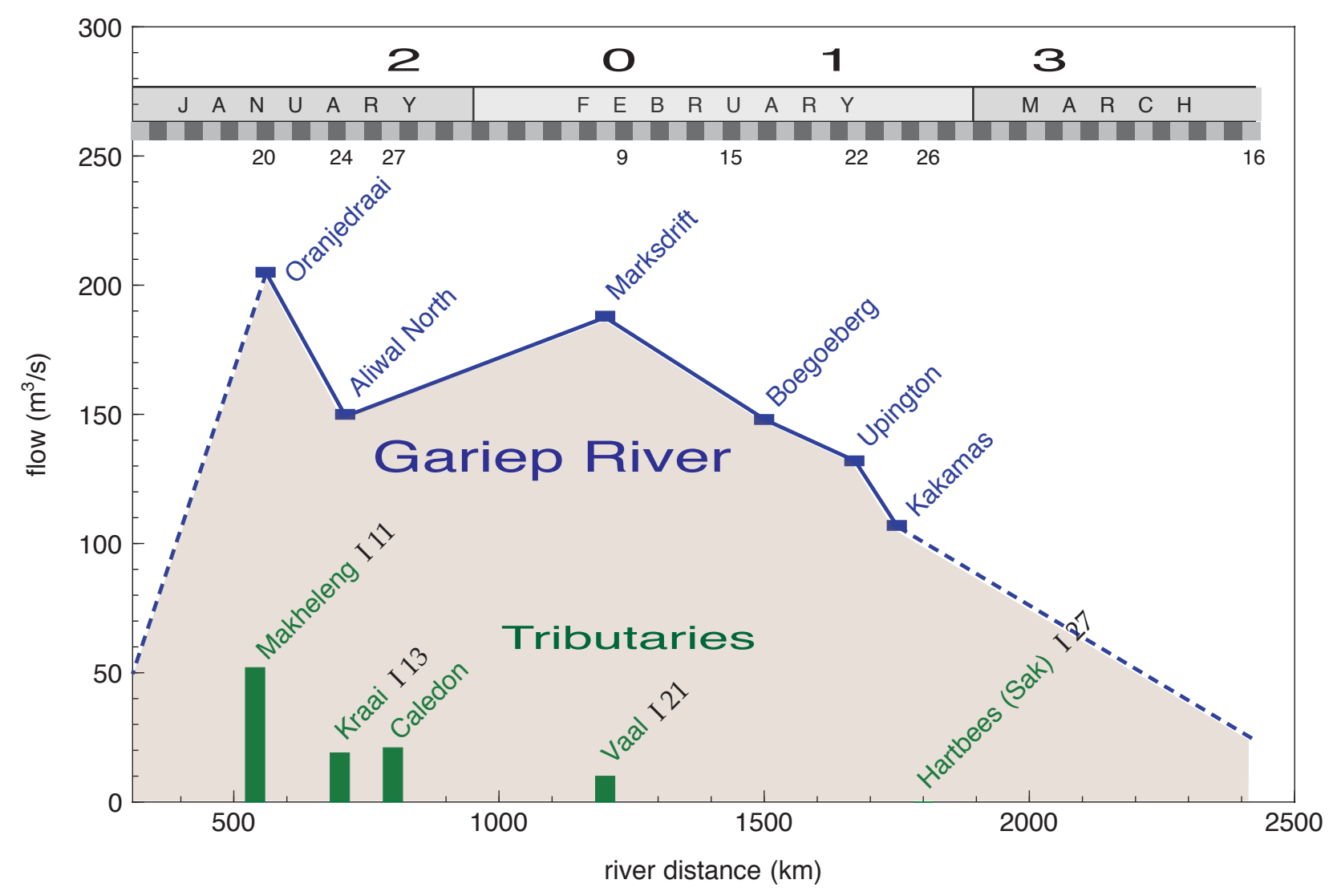

Figure 7: River flow rates from gauging stations on tributaries (bars) and the trunk stream (blocks on the line) of the Gariep River, at the time of sampling (Department of Water and Sanitation, 2015b). The lack of significant input from any tributaries in South Africa (downstream of Oranjedraai, at the border with Lesotho) is apparent. The flow in the Hartbees is too little to register on the graph. 


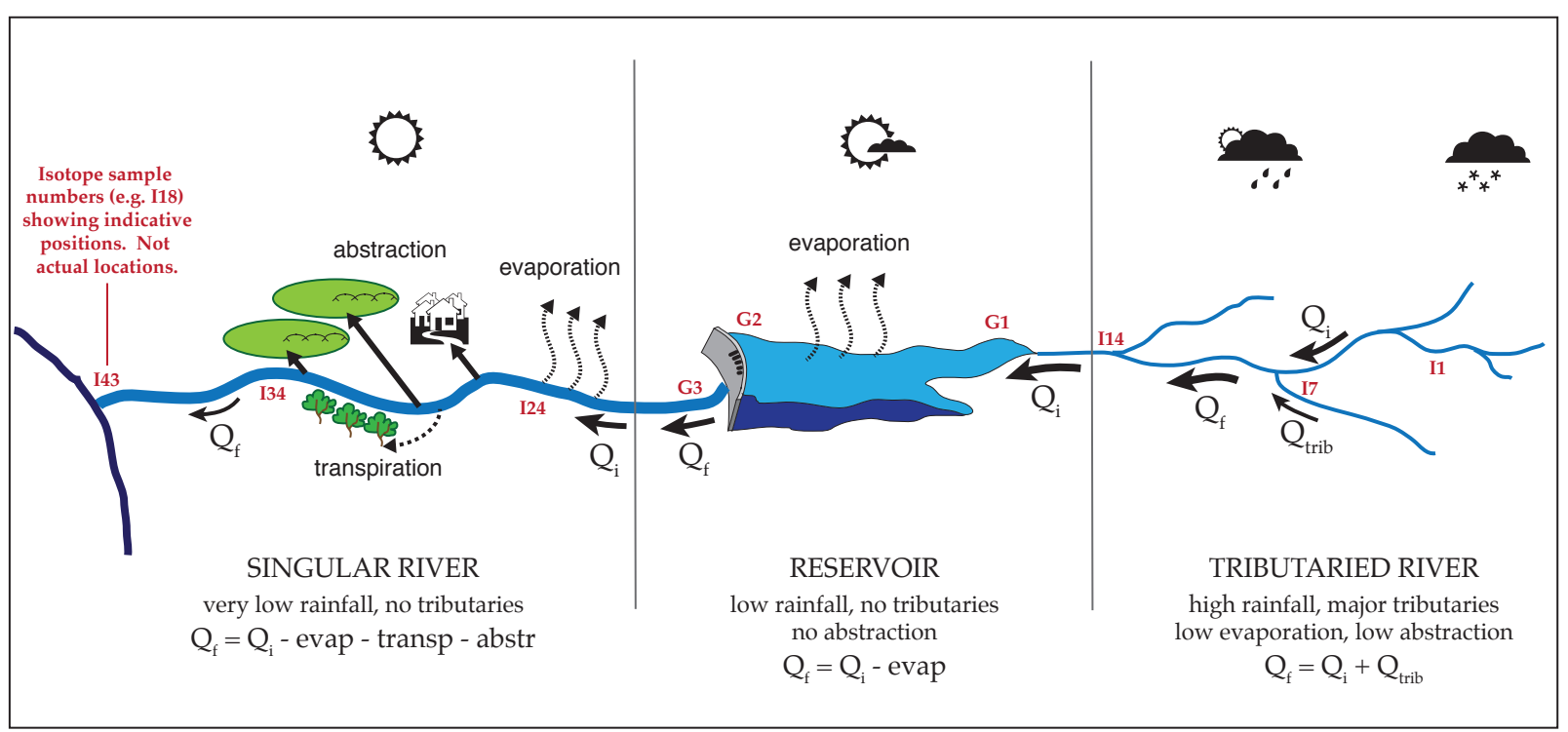

Figure 8: A schematic of the Gariep River, showing geographically distinct sections of river, on which different stable isotope calculations can be applied. For a tributaried river, contributions from tributaries can be calculated with one flow gauge measurement if stable isotope data exists for upstream and downstream of the confluence on the trunk stream, and for the tributary. For a reservoir, the proportion of evaporation can be calculated with only stable isotope data and if influent flow data is available, then the actual quantity of water evaporated can be calculated. For a "singular" river, where flow gauging data is available over a reach of river, the proportion of water abstracted can be calculated as that remainder of the losses after evaporation and transpiration have been accounted for.

high flows, respectively, for the stretch downstream of Vanderkloof Dam.

\subsection{Abstraction Calculations}

The lower half of the Gariep River is amongst a handful of major rivers globally where a substantial stretch of the river consists essentially of the trunk stream only, with no significant inputs from rain, surface water or groundwater. Other examples include the Nile, Colorado and Indus Rivers. Along this lower stretch of the Gariep, changes in flow are largely due to losses, which include evaporation, transpiration and abstraction. Evaporation has been calculated from changes in stable isotope composition. Transpiration does not cause fractionation of isotopes (Gonfiantini et al., 1965; Wershaw et al., 1966) and so its effect will be indistinguishable from that of abstraction. McKenzie and Craig (2001) estimated transpiration based on the area taken up by reeds and trees, applying a $1 \mathrm{x}$ and $0.5 \mathrm{x}$ factor, respectively, to the modelled evaporation expected from the same area of open water. These factors are in approximate agreement with recent studies apportioning water loss to transpiration and evaporation (Wei et al., 2015). 
This has been applied to the section of the Gariep River from Marksdrift gauging station, just above the confluence with the Vaal, to Kakamas gauging station. These stations record a change in flow from $189 \mathrm{~m}^{3} / \mathrm{s}\left(\mathrm{Q}_{i}\right)$ to $107 \mathrm{~m}^{3} / \mathrm{s}\left(\mathrm{Q}_{f}\right)$. Evaporation, calculated from the change in isotope composition, is $3.8 \%$ of inflow $\left(\mathrm{Q}_{i}\right)$, which equals $7.6 \mathrm{~m}^{3} / \mathrm{s}$ (the average of changes in $\delta \mathrm{D}$ and $\delta^{18} \mathrm{O}$ ). Transpiration, based on the work of McKenzie and Craig (2001), comes to $1.6 \mathrm{~m}^{3} / \mathrm{s}$. According to equation 12:

$$
A b=Q_{i}-Q_{f}-E T=189-107-(7.6+1.6)=83 m^{3} / s
$$

as shown in Figure 9. This is predominantly for farming, but also includes minor quantities for towns and other activities, such as mining. For the sake of alternative visualisation of this abstraction flow, given that the distance over which this calculation took place is $554 \mathrm{~km}$, the average abstraction can be determined as $175 \mathrm{~L} / \mathrm{s} / \mathrm{km}$ of river.

A similar calculation can be applied to the Lesotho to Vaal confluence stretch, yielding an abstraction value of $27 \mathrm{~m}^{3} / \mathrm{s}$, which, over the non-reservoir length of river, works out to 54 $\mathrm{L} / \mathrm{s} / \mathrm{km}$, as shown in Figure 9.

\section{Discussion}

\subsection{Validation of Stable Isotope Evaporation Model}

The near coincidence of the theoretically predicted final isotopic composition of an evaporating water body $\left(\delta^{*}\right)$ based on local conditions with the local evaporation line (LEL; see Figure 5) is taken as validation of the evaporation model. However, the location of $\delta^{*}$ along the line could shift, and so although the proximity of the point is a good indicator of model validity, it cannot be taken as absolute proof. Nonetheless, the proximity of the point and line is significant, as there are several equations, approximations and assumptions in the evaporation model, and this validation proves that either all the approximations and assumptions are close to correct, or there are some with positive bias and others with negative bias and these happen to cancel each other out for this study. Either way, for the purposes of this study, the validation of the model increases the reliability of the evaporation and abstraction results.

Various workers have questioned the validity of the kinetic fractionation factor $\left(\varepsilon_{K}\right)$ for D/H Zuber (1983); Biggs et al. (2015), in particular at low relative humidities, which applies to this study. However, the calculation of alternative $\varepsilon_{K}$ values according to Zuber (1983) relies on 


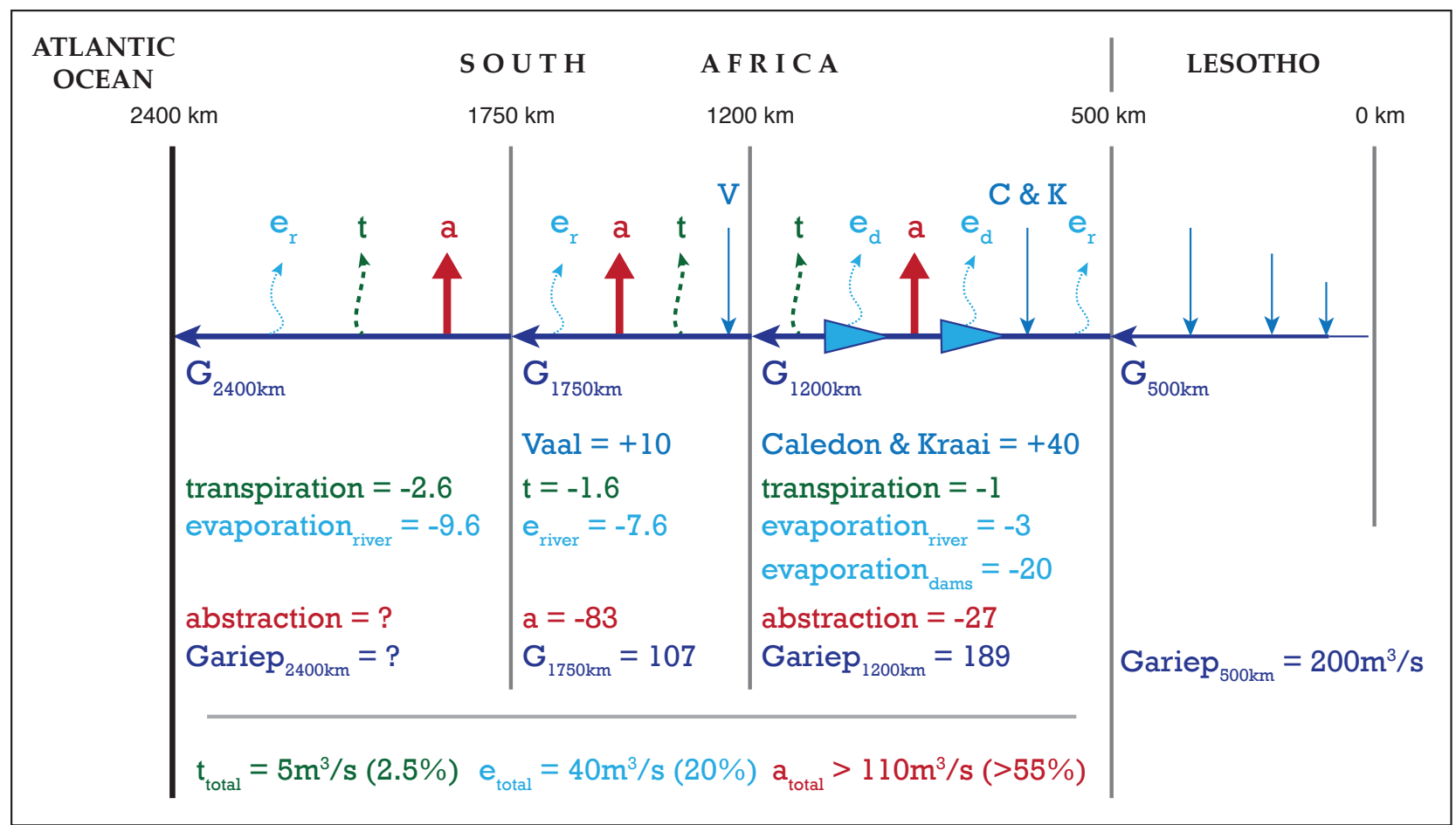

Figure 9: A summary of the hydrology of the Gariep River system during this study (JanuaryMarch 2013). Gariep and tributary river flows are from the gauging network (Department of Water and Sanitation, 2015b) and transpiration estimates from McKenzie and Craig (2001). Evaporation amounts were calculated from changes in stable isotope composition of river water, with abstraction being the remainder. All flows in $\mathrm{m}^{3} / \mathrm{s}$. Distances are along river, not straight line. 
already knowing the E/I fraction, determined from hydrological measurements. For this study, the E/I fraction is calculated from the stable isotope measurements and implementation of the evaporation model, so any attempt to recalculate a more suitable $\varepsilon_{K}$ would be based on circular reasoning and therefore invalid. The lack of this option to calculate a more suitable $\varepsilon_{K}$ value, especially given the low relative humidity environment, is partially dismissed by the apparent validation of the model. However, further studies on the Gariep River system should however investigate the option of calculating an improved $\varepsilon_{K}$ value. This would require use of a relatively closed system, or highly measured system, in the climate of interest. For these purposes, a reservoir with inflow and outflow monitoring of flow rates as well as stable istope compositions, and weather records (rainfall, temperature, humidity) would be the best option.

\subsection{Mass Balance Calculations}

The changes in stable isotope composition before and after a tributary were used to evaluate the accuracy of a mass balance method for estimating the flow in a tributary. There were unfortunately several factors that complicate the assessment of this method: the distance between the upstream and downstream samples, the variation in flow rates of the trunk and tributary streams, as well as the rather large difference between the results using $\delta \mathrm{D}$ and $\delta^{18} \mathrm{O}$ values. The calculation suggests that the method is useful, although probably suffers from errors of up to $50 \%$, based purely on the difference between the $\delta \mathrm{D}$ and $\delta^{18} \mathrm{O}$ results. As such, the method does not promise to answer detailed hydrological questions, but will allow a broad assessment of the hydrology of an ungauged system.

This approach could therefore provide an estimate of flow where gauging stations are few, unreliable or defunct, although care must be taken to ensure the downstream sample is taken far enough below the confluence for reasonable mixing of the tributary and trunk stream waters to have taken place (Krouse and McKay, 1971). Tens of kilometres will probably suffice in the case of the Gariep, the exact distance dependent on relative flow rates of the tributary and trunk stream, as well as the rate at which downstream mixing homogenises the confluent flows.

The mass balance method proved highly useful to show the minimal influence from low flowing tributaries. In this case, the Vaal River, one of only 4 significantly flowing tributaries downstream of Lesotho, had a relatively evaporated isotopic signature, but the flow was so low (due to high water use in the catchment) compared to the Gariep, that the effect on the downstream total isotopic composition was within laboratory error. The changes in isotope composition in the Gariep due to the Vaal input were $0.4 \%$ for $\delta \mathrm{D}$ and $0.1 \%$ for $\delta^{18} O$, which 
represents only $2.1 \%$ and $2.9 \%$ of the total change in isotope composition, respectively, recorded over the length of the Gariep River in this study.

It is possible that at times of higher Vaal to Gariep flow ratios that this river could indeed influence the isotope composition of the Gariep and change the conclusions of a similar study to this, but considering the extensive damming (around $10000 \mathrm{GL}$ ) and water use in the Vaal catchment, this is an unlikely scenario.

\subsection{Evaporation Calculations}

There are several possible issues with the evaporation calculations. These include aspects of the conceptual model for the flow of water in the Gariep River system, as well as details around the calculation of input parameters.

\subsubsection{Snapshot sampling}

The first conceptual issue is the representivity of the "snapshot" sampling approach used in this study. The Gariep River has basically two flow regimes, as described in the Hydrology section: a regulated normal-flow when regulation via dams and irrigation schemes keeps the flow low and fairly steady, and a flood-flow when all dams are full and flow responds to rainfall (Figure 4). The normal-flow regime is the more common and this was the situation in January - March 2013 when sampling took place. The samples are therefore representative of the most common river condition, but should a long term, wholistic view of evaporation and river flows be desired, then a long term sampling strategy over a decade or more will be necessary to incorporate the climatic cycles that cause normal-flow and flood-flow regimes.

\subsubsection{Non-in-stream-evaporative causes of isotope changes}

The second conceptual issue is around the assumption that evaporation is the sole cause of change in isotopic composition as the river water flows downstream. This assumption relies on there being no surface or groundwater input into the river. The first part of this is easily quantified, and has been dealt with above in the section on Hydrology; there is almost zero input of surface water below the Vaal River, and even the flows from the Vaal into the Gariep are generally less than $10 \%$ of the total Gariep flow. For this study, the Vaal was contributing at 10 $\mathrm{m}^{3} / \mathrm{s}$ into the Gariep at $190 \mathrm{~m}^{3} / \mathrm{s}$, a contribution of only $5 \%$ (Figure 7). Effects from tributaries higher up, such as the Caledon and Kraai, are minimal because of the relatively minor flow rate (each about $10 \%$ of the main stream), as well as the similarity of isotope composition to the 
main stream. The change caused in the isotope composition of the Gariep main stream is within analytical error and is considered to be negligible.

Natural groundwater contributions are much harder to assess and no studies have quantified baseflow into the Gariep River. As explained in the Evaporation Calculations section of the Results and outlined in Sections 2.3 Climate and 2.4 Hydrogeology, it is likely to be minimal, due to the dry climate and lack of primary porosity aquifers. This however, has yet to be proven.

Equally difficult to quantify are the irrigation return flows from the abundant agricultural activity along the banks of much of the Gariep River. Although irrigation return flows are generally minor at any point, the extensive nature of this diffuse contribution could result in a significant cumulative impact on river flow and isotope composition. Some international studies point to high levels of irrigation return flow, but these are often in areas with flood irrigation (Yoshida et al., 2016) or highly permeable aquifers (Sanford et al., 2011). In contrast, in a South African example, other workers found river flows to thoroughly dilute the effect of irrigation return flows on water quality (Pearse and Schumann, 2001). For the Vaal River, irrigation return flows were found to be $4-22 \%$ of irrigation use for intensive irrigation schemes (Mare, 2007). These numbers were estimated through water balance calculations and could therefore be inclusive of natural groundwater flow. Furthermore, these are likely to be the upper limit for return flows on the Gariep for the following reasons. The areas reported on are intensive irrigation schemes where cumulative water use is very high and likely to raise the water table locally. These areas are also in a climate that has more rain and less evaporation, with the result that infiltration will be higher, leading to greater interflow or recharge and therefore return flows. Return flow from irrigation schemes on the Gariep could therefore be more like 2-10\% of irrigation use.

The total irrigation demand on the Gariep River system is around 2100 GL/a, however, almost half of this is for interbasin transfers to areas outside the Gariep catchment (Mare, 2007). Furthermore, not all irrigated areas are close enough to the river to contribute to return flows, so a fair allocation for irrigation use close to the Gariep River is around 1000 GL/a. If irrigation return flow is assumed to be $5 \%$ of use, then return flows could be around $50 \mathrm{GL} / \mathrm{a}$, which is about $0.4 \%$ of MAR. No measurements are available on the isotope composition of irrigation return flow. However, even if severe evaporative enrichment occurs, with changes of $10-20 \%$ o $\delta$ and $2-4 \%$ o $\delta^{18} \mathrm{O}$, the dilution factor of around $250(0.4 \%$ of $100 \%)$ will render this contribution negligible to the overall isotope composition of river water in the Gariep River. 


\subsubsection{Cumulative and total E/I calculations}

The total evaporation from the Gariep River, calculated from stable isotopes, is $21.5 \%$ of inflow, based on a whole river calculation. Evaporation calculations can be performed on sections of river, and with the gauged water flows during the study, these percentages can be converted to flows: evaporation from both reservoirs being $20 \mathrm{~m}^{3} / \mathrm{s}$, and the total for the Gariep River amounting to $40 \mathrm{~m}^{3} / \mathrm{s}$. Discrepancies between values calculated over the length of the river versus the sum of several river reaches can be ascribed to abstraction losses from the river, which reduce the river flow and result in lower evaporation flows when converting from evaporation as an E/I percentage (\%) to evaporation as a flow rate $\left(\mathrm{m}^{3} / \mathrm{s}\right)$. For example, the $21.5 \%$ result is for a single calculation over the full length of the isotope survey, whilst the sum of 3 sections covering the same as the single calculation comes to $20 \%$. Similarly, the reservoir evaporation losses of $8.5 \%$ work out to be a similar flux to the river losses of $14.7 \%$ (both about $20 \mathrm{~m}^{3} / \mathrm{s}$ ), because of the lower flow on the downstream sections of the river.

\subsubsection{Uncertainties and errors}

A sensitivity analysis was conducted on the effect of air temperature (T) and relative humidity (h) values, because the weather stations do not record the exact air temperature and relative humidity values for air above the river surface where the evaporation takes place. A $2{ }^{\circ} \mathrm{C}$ difference in mean annual $\mathrm{T}$, up or down, caused a change in the $\mathrm{E} / \mathrm{I}$ value of only $\pm 0.2 \%$ for $\delta^{18} \mathrm{O}$ and $\pm 0.7 \%$ for $\delta$ D. Relative humidity had a greater effect, where a $10 \%$ increase, from $45 \%$ to $55 \%$ mean annual relative humidity, caused a $+1.5 \%$ and $+2.5 \%$ increase in final $\mathrm{E} / \mathrm{I}$ results for $\delta^{18} \mathrm{O}$ and $\delta$ D respectively. A reduction in relative humidity however, from $45 \%$ to $35 \%$, caused only a $-0.9 \%$ and $-1.5 \%$ change in the $\mathrm{E} / \mathrm{I}$ values for $\delta^{18} \mathrm{O}$ and $\delta \mathrm{D}$.

Although the weather stations are mostly located in towns on the river, they are not right at the water's surface and therefore do not record air temperature and relative humidity data for the river itself. However, the long term nature of this data is useful for this study, as the transit time for water from source to sea on the Senqu-Gariep river system is usually greater than one year, due to the size of the reservoirs (cumulatively 18900 GL) (Department of Water and Sanitation, 2015c) relative to mean annual runoff (11 000 GL) (Bremner et al., 1990). Further, as the relative humidity is probably slightly greater on the river itself than that measured at these stations, the kinetic fractionation effect will be less on the river. To achieve the measured change in isotope composition would therefore require a greater percentage evaporation than has been calculated using the lower relative humidity values at these weather stations. The 
evaporation percentages are, from this perpective, conservative.

\subsubsection{Comparison with hydrological modelling and other studies}

Using the rating curve for evaporation versus flow from McKenzie and Craig (2001), at $148 \mathrm{~m}^{3} / \mathrm{s}$, the average Gariep River flow below the Vanderkloof Dam during the sampling period for this study, they predict evaporation at $16 \%$. Their study covered a distance of $1400 \mathrm{~km}$, downstream of the Vanderkloof Reservoir, compared to $2000 \mathrm{~km}$ for this study. Although the upper reaches of the Gariep River would naturally experience little evaporation because of the cooler, more humid climate than the lower reaches, the two large reservoirs (Gariep and Vanderkloof) allow substantial evaporation to take place. Applying the E/I calculation to the same stretch of river as modelled by McKenzie \& Craig, yields $15.9 \%$ and $13.6 \%$ from changes in $\delta \mathrm{D}$ and $\delta^{18} \mathrm{O}$, with an average of $14.7 \%$, matching their estimate closely. A study in Texas, climatically similar to much of the Gariep catchment, calculated evaporation as $18 \%$ of total streamflow, also using modeled hydrological and climatic parameters (Wurbs and Ayala, 2014).

In one of the few studies using stable isotopes to calculate evaporation on a regional scale, Simpson and Herczeg (1991b) concluded that about 40\% of flow on the Murray River in Australia was lost to evaporation. This high value is partly because irrigation return flows contribute significantly to the river flow, and these irrigated regions experience very high evaporation losses. Farmers in Australia are compelled to irrigate generously to prevent build up of salinity, hence the substantial return flows. Also, as pointed out by Simpson and Herczeg (1991a), this applied only to summer months, as winter flow flushes the entire system and little evaporation results. The sunny, dry winter climate and large reservoirs on the Gariep ensure that evaporation is all year round, so the results of this work should remain similar during the year, whilst the Murray River evaporation estimate of $40 \%$ is likely to drop substantially when averaged over the hydrological year due to a decrease in evaporation and higher winter rainy season flows. Estimates, also using stable isotopes, for sub-catchments of the lower Yellow River, on the North China Plain, yield evaporation amounts averaging 14\% (Zhao and Li, 2017).

The study by McKenzie and Craig (2001) considered only in-channel evaporation and transpiration. This study seems to confirm their estimate closely and further shows that evaporation in the wider catchment seems to have little effect on the changes seen in isotope composition. Due to the hot, dry climate, irrigated water would be expected to develop a highly evaporated isotope signature, which would raise the E/I result higher than that calculated by McKenzie and Craig (2001). That this is not the case, confirms the insignificant nature of irrigation return 
flows, be they surface water or groundwater. All in all, the two independent studies come to remarkably close agreement given the scale of the investigation.

\subsection{Abstraction Calculations}

Calculation of abstraction amounts based on a water balance, using stable isotopes for calculating evaporation, has not been done before, or certainly not on this scale. To do so was dependent upon not only stable isotope measurements, but also having flow gauging data and estimates of transpiration. This shows the need for a multidisciplinary approach. Some of the methods listed in the introduction could be applied to this area to allow measurement of transpiration, or combined evapotranspiration, from both natural riparian vegetation, as well as irrigated crops. Solid regulation of water users, in which records of abstraction are kept, could also help corroborate the amounts calculated in this study. Plenty of room exists, at both a scientific level and management and regulation level, for improved understanding of the Gariep River's hydrology.

\subsection{Recommendations}

The use of stable isotopes to understand the hydrology of the Gariep catchment can be improved in several ways. A similar snapshot sample to this study should be performed when the river is in flood-flow mode, with all major reservoirs full and spilling at the same rate as inflow. This would give an understanding of the river in a different and more natural flow regime, even though this regime occurs less frequently than the regulated low-flow situation. A long term stable isotope study over a few years could also be performed with quarterly sampling of key points along the river, above and below major tributaries and reservoirs. This would remove possible errors associated with rain storms and seasonal variations.

To verify that the contribution made by irrigation return flow is indeed insignificant, or to attempt to quantify it, two approaches could be used. Either groundwater investigations using hydraulics (borehole and river water levels and aquifer pumping tests) on various soil and rock types along the length of the river, or water balance and evapotranspiration measurements on various crops or natural vegetation to estimate recharge could be used. Both approaches are challenging given the vast area with variation in geology, geomorphology, crop and natural vegetation types.

This study has potential application in other parts of the world. Each river system will have its own challenges, but the following pointers are given. Sampling should be done as quickly as possible from source to sea, during the dominant flow regime. Samples should be taken at least 
every $100 \mathrm{~km}$, but also include every significant tributary. Areas with major aquifers that feed into the river should quantify this contribution. All other available data on river flows, water use and meteorological measurements will be helpful to build a convincing model of the hydrology.

\section{Conclusions}

Stable isotopes of water provide a relatively fast and cheap method of calculating flow contributions from tributaries, evaporation from surface water bodies, and abstraction from rivers. The schematic of the Gariep River in Figure 8 illustrates the applicability of stable isotope measurements to making the above calculations on various sections of river, as determined by the geographical and hydrological character of the river. Reliable air temperature and relative humidity data are essential and long term precipitation monitoring for isotope composition can improve the accuracy of the calculations. Some flow gauging data are also necessary to convert relative amount data into absolute flows or quantities of water.

The $\delta \mathrm{D}-\delta^{18} \mathrm{O}$ position for the final isotope composition of an evaporating puddle $\left(\delta^{*}\right)$ lies almost on the independently calculated local evaporation line (LEL), verifying the validity of the isotope evaporation model as implemented in this study.

It was estimated that evaporation between Lesotho and the Atlantic Ocean on the Gariep River is around $20 \%$ of the flow, amounting to around 1300 GL/a, or about the annual consumption of water in Gauteng (the province encapsulating the cities of Pretoria and Johannesburg), corroborating previous estimates based on hydrological modelling. Projected increases in air temperature from climate change predictions would not affect evaporation substantially, although decreased relative humidity would have a significant impact.

Calculating the flow in a tributary is possible using isotopes, if either the upstream or downstream flow on the main river is known, and if there is a difference in isotope composition between the tributary and main river. Care must be taken to ensure the downstream isotope sample is well mixed.

Abstraction from a river with no inputs can be calculated if gauging station data is available and by applying the evaporation estimates from changes in isotope composition. This yielded results of $54 \mathrm{~L} / \mathrm{s} / \mathrm{km}$ for the upper middle and $175 \mathrm{~L} / \mathrm{s} / \mathrm{km}$ for the lower middle reaches of the Gariep River.

Given deteriorating monitoring networks and limitations on manpower and skills (Buschke and Esterhuyse, 2012) and the pressure on the Gariep River as a water resource from both the 
demand and supply side, stable isotopes offer an immediate solution to understanding evaporation, a major component of the water balance in a dry environment, and estimating abstraction. This study has highlighted the significant loss of water through evaporation from major reservoirs and has demonstrated the applicability of stable isotopes to the realm of major water resource modelling and management.

\section{Acknowledgments}

SJ received funding from the Plant Conservation Unit at the University of Cape Town and the South African Environment Observation Network. RD received funding from the Water Research Commission and the National Research Foundation. RD would like to thank the editors and anonymous reviewers for their constructive criticism, and Chris Harris and Adam West (University of Cape Town) for access to analytical facilities and Martin Kleynhans (Aurecon) for hydrological input.

\section{References}

Beaudoin, G., Therrien, P., 2014. AlphaDelta: Stable Isotope Fractionation Calculator. http://www2.ggl.ulaval.ca/cgi-bin/alphadelta/alphadelta.cgi.

Biggs, T.W., Lai, C.T., Chandan, P., Lee, R.M., Messina, A., Lesher, R.S., Khatoon, N., 2015. Evaporative fractions and elevation effects on stable isotopes of high elevation lakes and streams in arid western Himalaya. Journal of Hydrology 522, 239-249.

Bremner, J.M., Rogers, J., Willis, J.P., 1990. Sedimentological aspects of the 1988 Orange River floods. Transactions of the Royal Society of South Africa 47, 247-294.

Brutsaert, W., 1986. Catchment-scale evaporation and the boundary layer. Water Resources Research 22, 39S-45S.

Buschke, F.T., Esterhuyse, S., 2012. The perceptions of research values and priorities in water resource management from the 3rd Orange River Basin Symposium. Water SA 38, 249-253.

Cartwright, I., Hall, S., Tweed, S., Leblanc, M., 2009. Geochemical and isotopic constraints on the interaction between saline lakes and groundwater in southeast Australia. Hydrogeology Journal 17, 1991-2004. 
Chacko, T., Cole, D.R., Horita, J., 2001. Equilibrium oxygen, hydrogen and carbon isotope fractionation factors applicable to geologic systems, in: Valley, J.W., Cole, D.R. (Eds.), Stable Isotope Geochemistry. Mineralogical Society of America, Washington D.C.. volume 43 of Reviews in Mineralogy and Geochemistry. chapter 1, pp. 1-81.

Chen, X., Alimohammadi, N., Wang, D., 2013. Modeling interannual variability of seasonal evaporation and storage change based on the extended Budyko framework. Water Resources Research 46, 6067-6078.

Craig, H., Gordon, L.I., 1965. Deuterium and oxygen 18 variations in the ocean and the marine atmosphere, in: Tongiorgi, E. (Ed.), Stable Isotopes in Oceanographic Studies and Paleotemperatures. Proceedings of the Spoleto Conferences in Nuclear Geology, Pisa, pp. 9-130.

Dai, A., Wigley, T.M., 2000. Global Patterns of ENSO-induced Precipitation. Geophysical Research Letters 27, 1283-1286.

Deguchi, A., Hattori, S., Daikoku, K., Park, H.T., 2008. Measurement of evaporation from the forest floor in a deciduous forest through the year using microlysimeter and closed-chamber systems. Hydrological Processes 22, 3712-3723.

Dent, M.C., Lynch, S.D., Schulze, R.E., 1989. Mapping mean annual and other rainfall statistics over southern Africa. Technical Report 109/1/89. Water Research Commission. Pretoria.

Department of Water Affairs, 2013. Development of Reconciliation Strategies for Large Bulk Water Supply Systems: Orange River. Surface Water Hydrology and Systems Analysis Report. Technical Report P RSA D000/00/18312/7. Department of Water Affairs. Pretoria.

Department of Water Affairs and Forestry, 2003. Kimberley 2722. Technical Report. Government of South Africa.

Department of Water and Sanitation, 2015a. Hydrological services - surface water. https://www.dwa.gov.za/hydrology/.

Department of Water and Sanitation, 2015b. National Integrated Water Information System. http://niwis.dws.gov.za/.

Department of Water and Sanitation, 2015c. Surface water home page. $\quad$ URL: https://Www.dwaf.gov.za/Hydrology/Weekly/WMA.aspx. https://www.dwaf.gov.za/Hydrology/Weekly/WMA.aspx. 
Diamond, R.E., Harris, C., 1997. Oxygen and hydrogen isotope composition of Western Cape meteoric water. South African Journal of Science 93, 371-374.

Diamond, R.E., Harris, C., 2000. Oxygen and hydrogen isotope geochemistry of thermal springs of the Western Cape, South Africa: recharge at high altitude? Journal of African Earth Sciences 31, 467-481.

Dinçer, T., 1968. The use of oxygen 18 and deuterium concentrations in the water balance of lakes. Water Resources Research 4, 1289-1306.

Gammons, C.H., Poulson, S.R., Pellicori, D.A., Reed, P.J., Roesler, A.J., Petrescu, E.M., 2006. The hydrogen and oxygen isotopic composition of precipitation, evaporated mine water, and river water in Montana, USA. Journal of Hydrology 328, 319-330.

Gat, J.R., 1995. Stable isotopes of fresh and saline lakes., in: Lerman, A., Imboden, D., Gat, J. (Eds.), Physics and Chemistry of Lakes.. Springer, Berlin, pp. 139-165.

Gibson, J.J., Birks, S.J., Yi, Y., 2016. Stable isotope mass balance of lakes: a contemporary perspective. Quaternary Science Reviews 131, 316-328.

Gibson, J.J., Prepas, E.E., McEachern, P., 2002. Quantitative comparison of lake throughflow, residency, and catchment runoff using stable isotopes: modelling and results from a regional survey of Boreal lakes. Journal of Hydrology 262, 128-144.

Gibson, J.J., Reid, R., 2014. Water balance along a chain of tundra lakes: A 20-year isotopic perspective. Journal of Hydrology 519, 2148-2164.

Gonfiantini, R., 1986. Environmental Isotopes in Lake Studies, in: Fritz, P., Fontes, J.C. (Eds.), Handbook of Environmental Isotope Geochemistry. Elsevier, Amsterdam. volume 2. chapter 3, pp. 113-168.

Gonfiantini, R., Gratziu, S., Tongiorgi, E., 1965. Oxygen isotope composition of water in leaves, in: Isotopes and Radiation in Soil-Plant Nutrition Studies. International Atomic Energy Agency, Vienna, pp. 405-410.

Hewitson, B.C., Crane, R.G., 2006. Consensus between GCM climate change projections with empirical downscaling: precipitation downscaling over South Africa. International Journal of Climatology 26, 1315-1337. 
Horita, J., Weslowski, D.J., 1994. Liquid-vapor fractionation of oxygen and hydrogen isotopes of water from the freezing to the critical temperature. Geochimica Cosmochimica Acta 58, 3425-3437.

Jasechko, S., Sharp, Z., Gibson, J., Birks, S., Yi, Y., Fawcett, P., 2013. Terrestrial water fluxes dominated by transpiration. Nature 496, 347-350.

Jimenez, M.S., Cermak, J., Kucera, J., Morales, D., 1996. Laurel forests in Tenerife, Canary Islands: the annual course of sap flow in Laurus trees and stand. Journal of Hydrology 183, 307-321.

Johnson, M.R., Annhaeusser, C.R., Thomas, R.J. (Eds.), 2006. The Geology of South Africa. Geological Society of South Africa and Council for Geoscience, Johannesburg.

Kakiuchi, M., Matsuo, S., 1979. Direct measurements of D/D and 18O/16O fractionation factors between vapor and liquid water in the temperature range from 10 to $40 \mathrm{C}$. Geochemical Journal 13, 307-311.

Kalma, J.D., McVicar, T.R., McCabe, M.F., 2008. Estimating land surface evaporation: A review of methods using remotely sensed surface temperature data. Surveys in Geophysics 29, 421469.

Krouse, H.R., McKay, J.R., 1971. Application of $\mathrm{H}_{2}^{18} \mathrm{O} / \mathrm{H}_{2}^{16} \mathrm{O}$ abundances to the problem of lateral mixing in the Liard/McKenzie River System. Canadian Journal of Earth Sciences 8, 1107-1109.

Liu, J., Fu, G., Song, X., Charles, S.P., Zhang, Y., Han, D., Wang, S., 2010. Stable isotopic compositions in Australian precipitation. Journal of Geophysical Research 115, 16.

Ma, N., Zhang, Y., Guo, Y., Gao, H., Zhang, H., Wang, Y., 2015a. Environmental and biophysical controls on the evapotranspiration over the highest alpine steppe. Journal of Hydrology 529, 980-992.

Ma, N., Zhang, Y., Szilagyi, J., Guo, Y., Zhai, J., Gao, H., 2015b. Evaluating the complementary relationship of evapotranspiration in the alpine steppe of the Tibetan Plateau. Water Resources Research 51, 1069-1083.

Mare, H.G., 2007. Summary of Water Requirements from the Orange River. Orange River Integrated Water Resources Management Plan. Department of Water Affairs. 
Mayr, C., Lücke, A., Stichler, W., Trimborn, P., Ercolano, B., Oliva, G., Ohlendorf, C., Soto, J., Fey, M., Haberzettl, T., Janssen, S., Schäbitz, F., Schleser, G., Wille, M., Zolitschka, B., 2007. Precipitation origin and evaporation of lakes in semi-arid Patagonia (Argentina) inferred from stable isotopes $\left(\delta^{18} \mathrm{O}, \delta^{2} \mathrm{H}\right)$. Journal of Hydrology 334, 53-63.

McKenzie, R.S., Craig, A.R., 2001. Evaluation of river losses from the Orange River using hydraulic modelling. Journal of Hydrology 241, 62-69.

Midgley, J., Scott, D.F., 1994. The use of stable isotopes of water (D and ${ }^{18} \mathrm{O}$ ) in hydrological studies in the Jonkershoek Valley. Water SA 20, 151-154.

Moolman, J.H., 1946. The Orange River, South Africa. Geographical Review 36, 653-674.

National Oceanographic and Atmospheric Administration, 2015. State of the Climate. http://www.ncdc.noaa.gov/sotc.

Oki, T., Kanae, S., 2006. Global hydrological cycles and world water resources. Science 313, 1068-1072.

ORASECOM, 2007. Orange River Integrated Water Resources Management Plan: Review of Surface Water Hydrology in the Orange River Catchment. Technical Report ORASECOM 002/2007. Orange Senqu River Commission.

Pearse, M.W., Schumann, E.H., 2001. The impact of irrigation return flow on aspects of the water quality of the Upper Gamtoos Estuary, South Africa. Water SA 27, 367-372.

Preston-Whyte, R.A., Tyson, P.D., 1988. The Atmosphere and Weather of Southern Africa. Oxford University Press, Cape Town.

Rozanski, K., Araguás-Araguás, L., Gonfiantini, R., 1993. Isotopic patterns in modern global precipitation, in: Swart, P.K., Lohmann, K.C., McKenzie, J., Savin, S. (Eds.), Climate Change in Continental Isotopic Records. American Geophysical Union. number 78 in Geophysical Monograph. chapter 1, pp. 1-36.

Sanford, W.E., Olmo, K.D., Stednick, J.D., 2011. Quantifying irrigation return flows using stable isotopes of water along the South Platte River, Colorado, USA, in: American Geophysical Union Fall Meeting, p. 1116.

Schimmelman, A., DeNiro, M.J., 1993. Preparation of organic and water hydrogen for stable 
isotope analysis: Effects due to reaction vessels and zinc reagent. Analytical Chemistry 65, 789-792.

Shen, Y., Liu, C., Liu, M., Zeng, Y., Tian, C., 2010. Changes in pan evaporation over the past 50 years in the arid region of China. Hydrological Processes 24, 225-231.

Simpson, H.J., Herczeg, A.L., 1991a. Salinity and evaporation in the River Murray Basin, Australia. Journal of Hydrology 124, 1-27.

Simpson, H.J., Herczeg, A.L., 1991b. Stable isotopes as an indicator of evaporation in the River Murray, Australia. Water Resources Research 27, 1925-1935.

Skrzypek, G., Mydlowski, A., Dogramaci, S., Hedley, P., Gibson, J.J., Grierson, P.F., 2015. Estimation of evaporative loss based on the stable isotopes composition of water using Hydrocalculator . Journal of Hydrology 523, 781-789.

Socki, R.A., Karlsson, H.R., Gibson, Jr., E.K., 1992. Extraction technique for the determination of oxygen-18 in water using preevacuated glass vials. Analytical Chemistry 64, 829-831.

van Vuuren, L., 2015. Drought management - Strengthening our knowledge armoury. Water Wheel 14, 14-17.

Vegter, J.R., 2006. Hydrogeology of Groundwater. Region 26: Bushmanland. Technical Report TT 285/06. Water Research Commission. Pretoria.

Vogel, J.C., van Urk, H., 1975. Isotopic composition of groundwater in semi-arid regions of southern Africa. Journal of Hydrology 25, 23-36.

Water Research Commission, 2016. Water Resources of South Africa 2012 Study. http://www.waterresourceswr2012.co.za/.

Wei, Z., Yoshimura, K., Okazaki, A., Kim, W., Liu, Z., Yokoi, M., 2015. Partitioning of evapotranspiration using high-frequency water vapor isotopic measurement over a rice paddy field. Water Resources Research 51, 3716-3729.

Wershaw, R.L., Friedman, I., Heller, S.J., Frank, P.A., 1966. Hydrogen isotope fractionation of water passing through trees, in: Hobson, G.D. (Ed.), Advances in Organic Geochemistry. Pergamon, New York, pp. 55-67. 
West, A.G., Goldsmith, G.R., Matimati, I., Dawson, T.E., 2011. Spectral analysis software improves confidence in plant and soil water stable isotope analyses performed by isotope ratio infrared spectroscopy (IRIS) . Rapid Communications in Mass Spectrometry 25, 2268-2274.

Wever, L.A., Flanagan, L.B., Carlson, P.J., 2002. Seasonal and interannual variation in evapotranspiration, energy balance and surface conductance in a northern temperate grassland. Agricultural and Forest Meteorology 112, 31-49.

Woodford, A.C., Chevallier, L., 2002. Hydrogeology of the Main Karoo Basin: Current Knowledge and Future Research Needs. Technical Report TT179/02. Water Research Commission. Pretoria.

Wright, I.R., Harding, R.J., 1993. Evaporation from natural mountain grassland. Journal of Hydrology 145, 267-283.

Wurbs, R.A., Ayala, R.A., 2014. Reservoir evaporation in Texas, USA. Journal of Hydrology 510, $1-9$.

Yoshida, T., Masumoto, T., Horikawa, N., Kudo, R., Minakawa, H., Nawa, N., 2016. River basin scale analysis on the return ratio of diverted water from irrigated paddy areas. Irrigation and Drainage 65, 31-39.

Zhao, X., Li, F., 2017. Isotope evidence for quantifying river evaporation and recharge processes in the lower reaches of the Yellow River. Environmental Earth Science 76.

Zuber, A., 1983. On the environmental isotope method for determining the water balance components of some lakes. Journal of Hydrology 61, 409-427. 